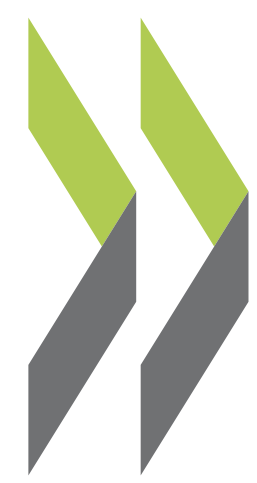

OECD Economics Department Working Papers No. 1516

\section{Improving skills}

and their use in Germany

\section{Andrés Fuentes Hutfilter,}

Stephanie Lehmann,

Eun Jung Kim 
ECONOMICS DEPARTMENT

\section{IMPROVING SKILLS AND THEIR USE IN GERMANY \\ ECONOMICS DEPARTMENT WORKING PAPERS No. 1516}

\section{By Andrés Fuentes Hutfilter, Stephanie Lehmann and Eun Jung Kim}

OECD Working Papers should not be reported as representing the official views of the OECD or of its member countries. The opinions expressed and arguments employed are those of the author(s).

Authorised for publication by Álvaro Pereira, Director, Country Studies Branch, Economics Department.

All Economics Department Working Papers are available at www.oecd.org/eco/workingpapers.

JT03440116 
OECD Working Papers should not be reported as representing the official views of the OECD or of its member countries. The opinions expressed and arguments employed are those of the author(s).

Working Papers describe preliminary results or research in progress by the author(s) and are published to stimulate discussion on a broad range of issues on which the OECD works.

Comments on Working Papers are welcomed, and may be sent to OECD Economics Department, 2 rue André Pascal, 75775 Paris Cedex 16, France, or by e-mail to eco.contact@oecd.org.

All Economics Department Working Papers are available at www.oecd.org/eco/workingpapers.

This document and any map included herein are without prejudice to the status of or sovereignty over any territory, to the delimitation of international frontiers and boundaries and to the name of any territory, city or area.

The statistical data for Israel are supplied by and under the responsibility of the relevant Israeli authorities. The use of such data by the OECD is without prejudice to the status of the Golan Heights, East Jerusalem and Israeli settlements in the West Bank under the terms of international law.

On 3 May 2018, the OECD Council invited Lithuania to become a Member. At the time of publication the deposit of Lithuania's instrument of accession to the OECD Convention was pending and therefore Lithuania does not appear in the list of OECD Members and is not included in the OECD zone aggregates.

On 25 May 2018, the OECD Council invited Colombia to become a Member. At the time of publication the deposit of Colombia's instrument of accession to the OECD Convention was pending and therefore Colombia does not appear in the list of OECD Members and is not included in the OECD zone aggregates.

\section{(C) OECD (2018)}

You can copy, download or print OECD content for your own use, and you can include excerpts from OECD publications, databases and multimedia products in your own documents, presentations, blogs, websites and teaching materials, provided that suitable acknowledgment of OECD as source and copyright owner is given. All requests for commercial use and translation rights should be submitted to rights@oecd.org 


\section{ABSTRACT/RÉSUMÉ}

\section{Improving skills and their use in Germany}

Cognitive skills, such as reading and numeric skills, are key determinants of wages, employment and long-term economic growth. Good cognitive skills also reduce poverty risk and improve nonmaterial wellbeing, such as health and social cohesion. Non-cognitive skills, such as skills to use information and communication technology as well as managerial skills, also help workers adapt to new technologies and globalisation. In Germany cognitive skills among adults are above OECD average, but weaker than in leading economies, especially among individuals with low and middle qualifications. Much progress has been made to improve learning outcomes of youth with disadvantaged socio-economic background. Nonetheless, high-quality childcare, early childhood and full-day primary education still need to expand. The vocational education system is very successful in integrating young people well in the labour market. Strengthening general education within the successful vocational education and training system could help ensure the capacity of graduates to adapt to technological change at higher age in the future. Participation in life-long learning could be encouraged by better addressing individual training needs. This could improve prospects for adults without professional qualifications. Women's skills are used less well than men's, calling for policies to address gender imbalances in the labour market.

This Working Paper relates to the 2018 OECD Economic Survey of Germany

(http://www.oecd.org/eco/surveys/economic-survey-germany.htm)

JEL classification: I24, I25, I28, J31, J61, J62, J68

Keywords: skills, education, cognitive skills, wages, employment, lifelong learning, vocational education and training, mismatch, childcare, early childhood education, primary education, full-day schooling.

\section{Améliorer les compétences et leur utilisation en Allemagne}

Les compétences cognitives, comme la compréhension de l'écrit et les compétences numériques, sont des déterminants essentiels des salaires, de l'emploi et de la croissance économique à long terme. Posséder un bon niveau de compétences cognitives aide également à réduire le risque de pauvreté et à améliorer le bien-être non matériel, notamment l'état de santé et la cohésion sociale. Quant aux compétences non cognitives, notamment celles qui permettent d'utiliser les technologies de l'information et de la communication ainsi que les compétences managériales, elles facilitent l'adaptation de la main-d'œuvre aux nouvelles technologies et à la mondialisation. En Allemagne, si le niveau des compétences cognitives est supérieur à la moyenne de l'OCDE parmi les adultes, il est inférieur à celui observé dans les principales économies, en particulier parmi les individus peu et moyennement qualifiés. De nombreux progrès ont été accomplis pour améliorer l'acquisition de compétences parmi les jeunes issus de mieux socio-économiques défavorisés. Il reste toutefois qu'il faut continuer d'étoffer une offre de qualité en termes de services de garde d'enfants, d'éducation et d'accueil de la petite enfance et de scolarité à temps plein dans l'enseignement primaire. Le système de formation professionnelle donne de très bons résultats s'agissant de l'insertion des jeunes sur le marché du travail. Si l'on renforçait l'enseignement général au sein de ce système, performant, de l'enseignement et la formation professionnels (EFP), la capacité des diplômés à s'adapter ultérieurement au changement technologique au fur et à mesure de leur avancement dans la vie pourrait en être assurée. La participation à la formation tout au long de la vie pourrait être encouragée en répondant mieux aux besoins individuels de formation. Les perspectives des adultes sans qualification professionnelle pourraient en être améliorées. Enfin, les compétences des femmes sont moins utilisées que celles des hommes, ce qui impose de prendre des mesures destinées à corriger les déséquilibres hommes-femmes du marché du travail

Ce Document de travail se rapporte à l'Étude économique de l'OCDE de l'Allemagne, 2018

(http://www.oecd.org/fr/eco/etudes/etude-economique-allemagne.htm)

Classification JEL: I24, I25, I28, J31, J61, J62, J68

Mots clefs: compétences, formation, compétences cognitives, salaires, emploi, formation tout au long de la vie, l'enseignement et la formation professionnels, inadéquation des compétences, services de garde d'enfants, éducation et accueil des jeunes enfants, école primaire, école à temps plein 


\section{Table of contents}

Improving skills and their use in Germany............................................................................................... 6

Adult skills are a major determinant of long-term growth and wellbeing ..................................... 6

Educational attainment is strong and has improved modestly across generations ............................ 8

Adult cognitive skills are somewhat lower than in best-performing countries .............................. 13

Improving the matching of worker skills to jobs could boost productivity ...................................... 15

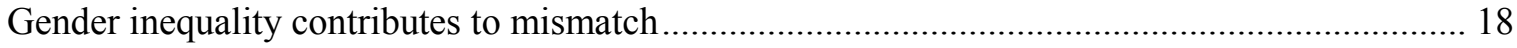

Removing geographical barriers to mobility can reduce mismatch ................................................. 21

Inclusiveness has improved but more progress would boost skills................................................. 22

Education outcomes of disadvantaged youth have improved strongly but early tracking may still

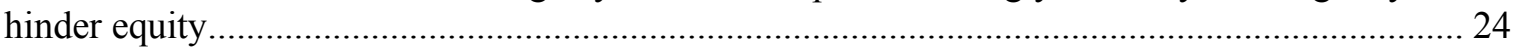

Further improving early childhood education and care and full-day primary education ................ 26

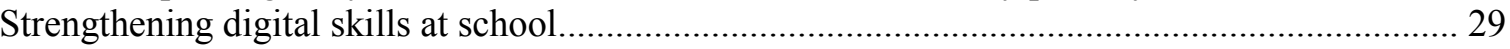

Adapting the successful vocational education system in the light of skill-biased technological change

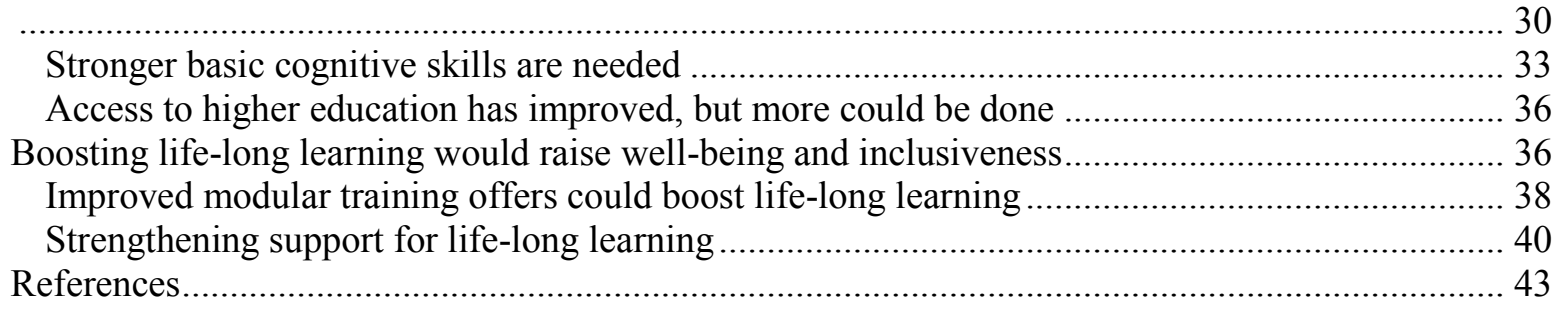

Tables

Table 1. Employment rates by educational attainment and age group, 2016

Figures

Figure 1. Education, literacy proficiency and use of reading at work boost wages .............................. 7

Figure 2. Almost all Germans have attained at least upper secondary education ................................... 9

Figure 3. Most adults possess upper secondary vocational degrees ................................................. 10

Figure 4. Most German youth are either in employment, education or in training ............................... 11

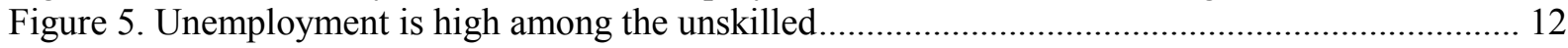

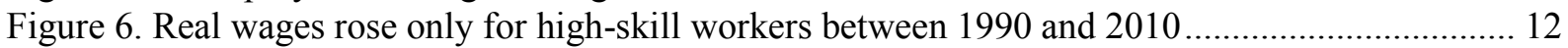

Figure 7. Adult skills are above OECD average, but lower than in leading OECD countries, especially in literacy.....

Figure 8. Performance gaps with respect to leading countries are larger for adults with low and intermediate

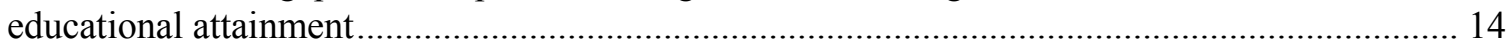

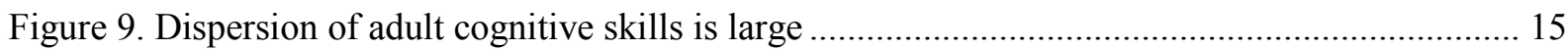

Figure 10. ICT skills are lower than in leading countries, especially among the young ....................... 15

Figure 11. Field-of-study mismatch is low but overqualification is above the OECD average ........... 17

Figure 12. Reducing mismatch boosts productivity ...................................................................... 18

Figure 13. The earnings gap between men and women is particularly large among highly educated workers

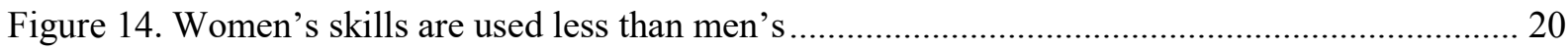


Figure 15. Low parental education is an important predictor of skills 23

Figure 16. The share of resilient students has increased strongly over the past 9 years....................... 25

Figure 17. Disadvantaged students are at higher risk of low performance ${ }^{1}$........................................ 26

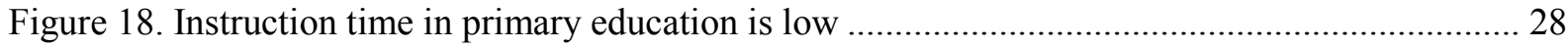

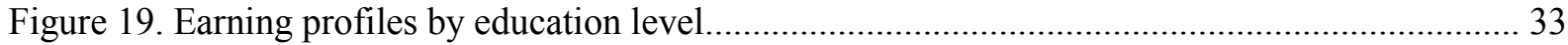

Figure 20. Literacy skills improve modestly in upper secondary vocational education......................... 34

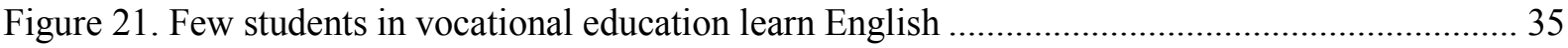

Figure 22. Participation in life-long learning can be raised further..................................................... 38

\section{Boxes}

Box 1. The OECD Programme for the International Assessment of Adult Competencies (PIAAC) ..... 6

Box 2. Impact of skills on earnings, productivity and wellbeing .................................................. 7

Box 3. Skill mismatch measures in the OECD PIAAC study .............................................................. 16

Box 4. Realising the potential of full-day school to boost cognitive and non-cognitive skills: Results of

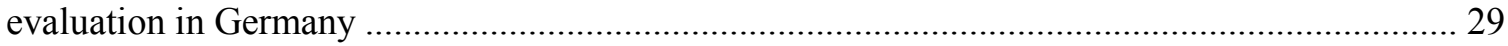

Box 5. Institutional responsibilities in Germany's vocational education and training system .............. 31 


\title{
Improving skills and their use in Germany
}

\author{
By Andrés Fuentes Hutfilter, Stephanie Lehmann and Eun Jung Kim ${ }^{1}$
}

\section{Adult skills are a major determinant of long-term growth and wellbeing}

Skills are a strong determinant of economic growth. For example, simulations have suggested that an improvement from a middle to a top-range position across OECD countries in average cognitive skills over a 20 -year period would raise GDP by $4 \%$ after 35 years and by more than $25 \%$ after 75 years (Hanushek and Woessmann, $2008_{[1]}$ ) mostly by boosting productivity. The link between skills measures and growth is particularly strong for Germany (Hanushek et al., 2015 $5_{[2]}$ ). The OECD Programme for the International Assessment of Adult Competencies allows analysing skills in the adult population and their impact across countries (PIAAC; Box 1).

\section{Box 1. The OECD Programme for the International Assessment of Adult Competencies (PIAAC)}

The PIAAC survey is based on a questionnaire administered to individuals in households representing the population aged between 16 and 65 . On average, across countries, $77.5 \%$ of participants were assessed on a computer, while the rest took the paper-based assessment. It was designed to measure key cognitive and workplace skills and provides indicators on the proficiency of individuals in literacy, numeracy and problem-solving in technology-rich environments, measured on a 500-point scale. PIAAC has extensive information on skill use at work and at home and background variables such as educational attainment, employment status, job, socio-economic background and personal characteristics. Most participating OECD countries, including Germany, conducted the survey in 2011-2012. Further countries conducted the Survey in 2014-15.

Source: Adalet McGowan, M. and D. Andrews (2017), "Skills mismatch, productivity and policies: Evidence from the second wave of PIAAC", OECD Economics Department Working Papers, No. 1403.

Cognitive and non-cognitive skills also raise individual employment and wage prospects substantially. They put individuals in a better position to take advantage from technological change and globalisation. Moreover, skills have substantial impacts on other wellbeing dimensions, such as health. How much workers can use their skills at the workplace also

1 Andrés Fuentes Hutfilter is Senior Economist in the Economics Department of the OECD. Stephanie Lehmann is Economist in the German Federal Ministry of Economic Affairs and Energy and was seconded to the Economics Department of the OECD while preparing this paper. Eun Jung Kim is Statistician in the Economics Department of the OECD. The paper enjoyed valuable inputs from François Keslair and Viktoria Kis (OECD/EDU). The authors are grateful for comments and suggestions by Alvaro Pereira, Isabell Koske, Robert Ford, Asa Johansson, Naomitsu Yashiro, Sahra Sakha (OECD/ECO), Arno Engel, Samuel Kim, Patricia Mangeol and William Thorn (OECD/EDU), Stijn Broecke and Glenda Quintini (OECD/ELS). All remaining errors are the authors' own. Special thanks are due to Carolina González, Dacil Kurzweg and Elisabetta Pilati $(\mathrm{OECD} / \mathrm{ECO})$ for their editorial work. 
has an impact on their wages, productivity and job satisfaction (Box 2). Hence, policies which strengthen workers' skills and their use are key for wellbeing and competitiveness. As this working paper will argue, Germany has a strong vocational skills system, supporting an excellent integration of young people in the labour market as well as the country's specialisation in high-productivity technology-intensive manufacturing and sophisticated business services. Germany has also made reforms to improve education outcomes, in particular among pupils with a disadvantaged socio-economic background. Nonetheless, looking into the future, demographic ageing and skill-biased technological change pose additional challenges, to which the skills system needs to adapt to make sure it continues to deliver. Scope also remains to boost skills among individuals with disadvantaged socio-economic background.

\section{Box 2. Impact of skills on earnings, productivity and wellbeing}

Among the adult population, three years more of full-time education is associated with almost $20 \%$ higher wages in Germany, according to the PIAAC study. In addition, adults with the same education level but higher reading proficiency earn substantially higher wages. These impacts are bigger in Germany than in many other OECD countries (Figure 1), which may reflect stronger specialisation on skill-intensive activities than in other OECD countries. Cognitive skills also raise employment prospects. This impact rises with age, suggesting that skills are also important to make the most of ageing (Hanushek et al., 2015 $5_{[3]}$ ). Competencies related to information and communication technology are also strongly related to higher wages (Hanushek et al., 2015 $5_{[3]}$ ).

\section{Figure 1. Education, literacy proficiency and use of reading at work boost wages}

Percentage change in wages associated with a change of one standard deviation in years of education, proficiency in literacy and use of reading at work

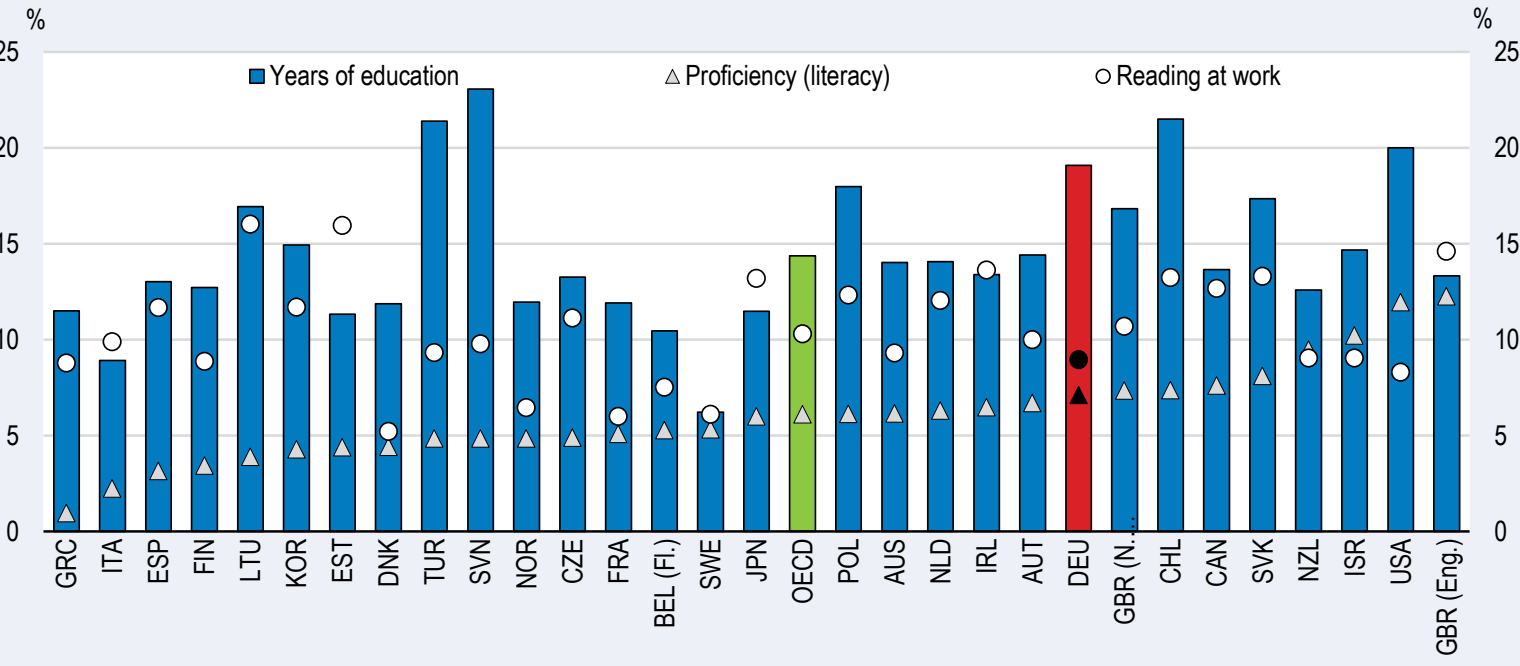

Note: Hourly wages, including bonuses, in PPP-adjusted USD (2012). Coefficients from the OLS regression of $\log$ hourly wages on years of education, proficiency and use of reading skills at work, directly interpreted as percentage effects on wages. Coefficients adjusted for age, gender, foreign-born status and tenure. The wage distribution was trimmed to eliminate the 1 st and 99th percentiles. One standard deviation in proficiency in literacy is 48 points. One standard deviation in years of education is 3.2 years.

Source: OECD (2016), Skills Matter: Further Results from the Survey of Adult Skills. 
Controlling for proficiency, greater use of reading, writing and ICT skills is also correlated with higher hourly labour productivity. This is shown for the use of reading at work in Figure 1. How much workers use their skills at the workplace has an even stronger impact on wages than skills themselves (OECD, 2016 [4] ). These findings suggest that policies need not only support skills but also skills use. Improving skills use also requires making skills more visible e.g. through forms of assessment and recognition of skills (see also below).

Cognitive skills are also an important determinant of participation in global value chains (GVCs) and associated productivity gains. For example they help workers incorporate imported technology-rich goods in domestic production. Countries can also reduce workers' exposure to the risk of job displacement by investing in skills, as some skills are more difficult to outsource.

Non-cognitive skills are also important so workers can make the most of technological change and globalisation. Jobs that involve face-to-face interactions, the need to be onsite, and decision making are less easy to offshore. ICT skills, management and communication skills, and readiness to learn show a significant positive correlation with productivity and the capacity to supply products to GVCs.

Better education and skills has contributed to lengthening life expectancy. More intensive use of skills is also associated with better job satisfaction (OECD, 2016 [4] $)$. More literate adults are more likely to engage in volunteering, trust other humans more and have more confidence in their own capacity to influence collective decision-making. Social skills are strongly related to life satisfaction and, to a lesser extent, self-rated health (Kosse et al., 2016 $\left.6_{[5]}\right)$. The important role of education and acquired skills in upward social mobility has also been well documented.

The impact of skills on economic growth, income and wellbeing is reinforced by skillbiased technological change (Chapter 1 of the 2018 Economic Survey of Germany). Hanushek and co-authors argue that more rapid economic change boosts the returns to cognitive skills, as they put workers in a better position to take advantage of technological change and reduce the risk of being left behind. Indeed, in countries with a strong record of economic growth, individual returns to adult numeracy skills tend to be higher (Hanushek et al., 2017 $[6]$ ).

\section{Educational attainment is strong and has improved modestly across generations}

Some $86 \%$ of adults in Germany have obtained at least an upper secondary qualification (equivalent to an apprenticeship degree or an academic degree qualifying for university entry), more than in most OECD countries (Figure 2). The share of the population with at least upper secondary education has been fairly stable over the generations. Some $13 \%$ of young people between 20 to 29 years old are without a qualification and this share has fallen little in recent years (Bundesinstitut für Berufsbildung, 2016 $\left.6_{[7]}\right)$. Some countries (such as Korea, Poland, Canada or Switzerland) have succeeded in reducing this share more than Germany.

While tertiary attainment has increased, it remains slightly below the OECD average. The share of young adults with a master's or doctoral degree is comparable to OECD averages, but in OECD comparison there are relatively fewer graduates leaving university with a short-cycle qualification such as a bachelor's degree. Unlike elsewhere in the OECD, 
tertiary attainment across all age groups is slightly lower among women than among men and is broadly balanced among young Germans.

\section{Figure 2. Almost all Germans have attained at least upper secondary education}

Share of population by educational attainment, by age group and gender, $2016^{1}$

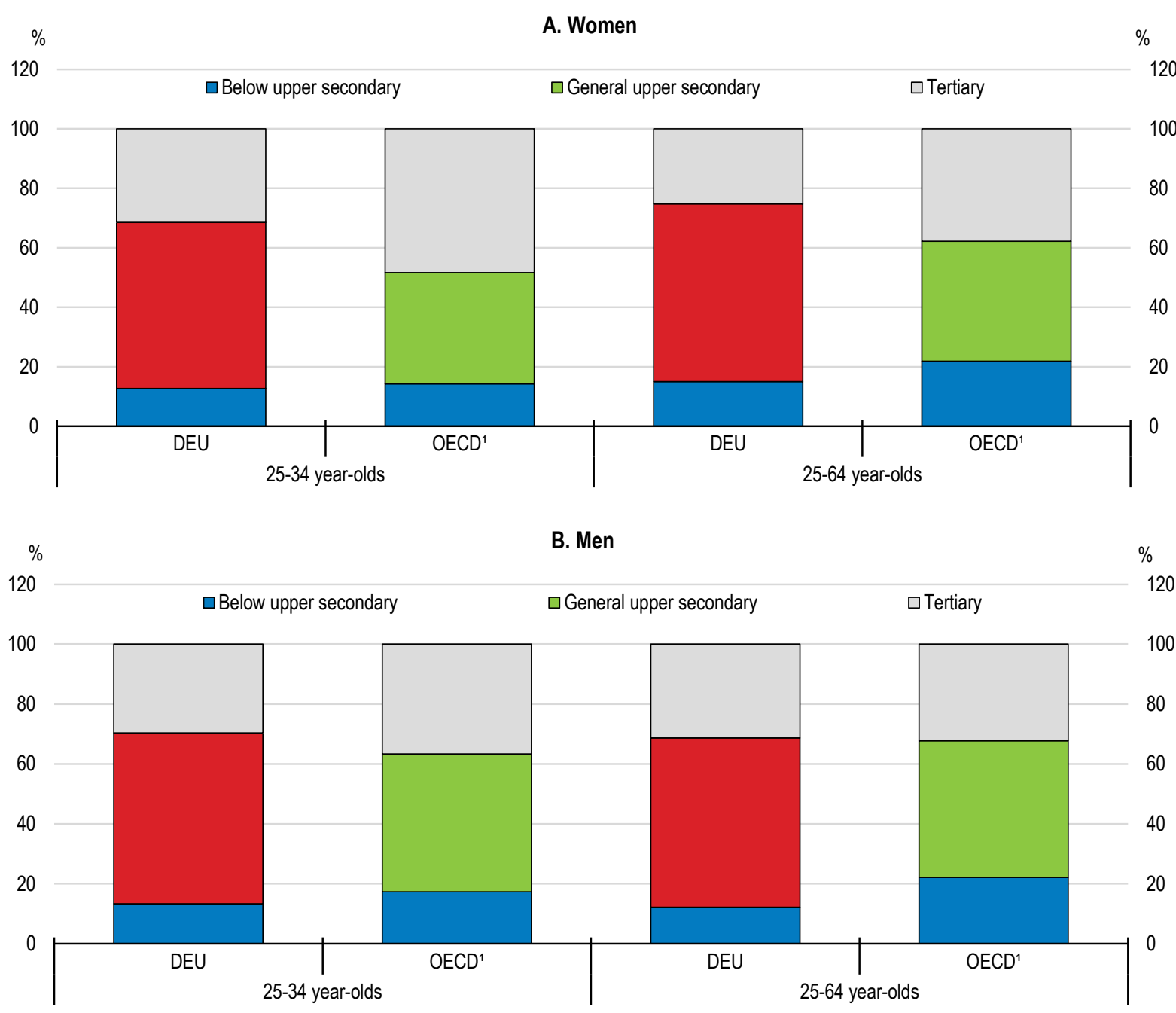

1. Unweighted average of OECD countries excluding Japan and including data in 2015 for Chile and Ireland. Source: OECD (2017), "Education at a glance: Educational attainment and labour-force status", OECD Education Statistics (database).

StatLink त्ञात्री http://dx.doi.org/10.1787/888933738293

Around half of the adult population in Germany has a vocational upper secondary or postsecondary non-tertiary qualification when they leave full-time education (Figure 3). This share is little lower among 25 to 34 year-olds. About $75 \%$ of youth in vocational education and training (VET) pursue an apprenticeship within the dual education system. The remaining $25 \%$ pursues school-only vocational education, which mostly provides training for health and social service occupations. Dual VET programmes can take between two and three and a half years to complete. However, the number of young people in vocational education diminished between 1991 and 2009 from 1.6 million to 1.3 million (Sachverständigenrat, 2017 ${ }_{[8]}$ ). This trend mainly reflects diminishing demand 
for apprenticeships, in part because youth cohorts have shrunk. In addition, the number of children who entered the academic track in lower secondary education has increased. This track provides the main access pathway to university education. The choice of track is therefore an important determinant of the decision to pursue academic or vocational education. Rising educational attainment in the parent generation has likely contributed to this trend, as the parental social and education background is a key determinant of the choice of lower secondary school track (Sachverständigenrat deutscher Stiftungen für Integration und Migration, 2013 $\left.{ }_{[9]}\right)$. Structural shifts in employment towards the services, where apprenticeships are less widespread, a higher demand for theoretical and general skills in the context of a more knowledge-intensive economy, and a declining willingness of small firms to offer apprenticeships may be further reasons (Mohr, Troltsch and Gerhards, $\left.2015_{[10]}\right)$. However, for the first time since 2011, the number of newly enrolled vocational students increased in 2017.

The percentage of young people going to academic upper secondary education, which prepares for university entry, rose from $31 \%$ to $52.8 \%$ since 1992 . Most pupils in academic upper secondary education eventually go to university, although some will first do an apprenticeship. The number of youth studying for a university degree is therefore likely to continue rising while the number of youth entering the labour market after obtaining upper secondary vocational degrees is therefore likely to diminish. On the other hand, many students who do not complete their university studies continue their professional careers by doing an apprenticeship instead (Heublein et al., 2017 ${ }_{[11]}$ ). Combining an apprenticeship with university studies, following an upper secondary academic degree, is especially widespread in financial services.

Figure 3. Most adults possess upper secondary vocational degrees

Percentage of 25-64 year-olds whose highest level of education is upper-secondary or post-secondary nontertiary, by programme orientation, $2016^{1}$

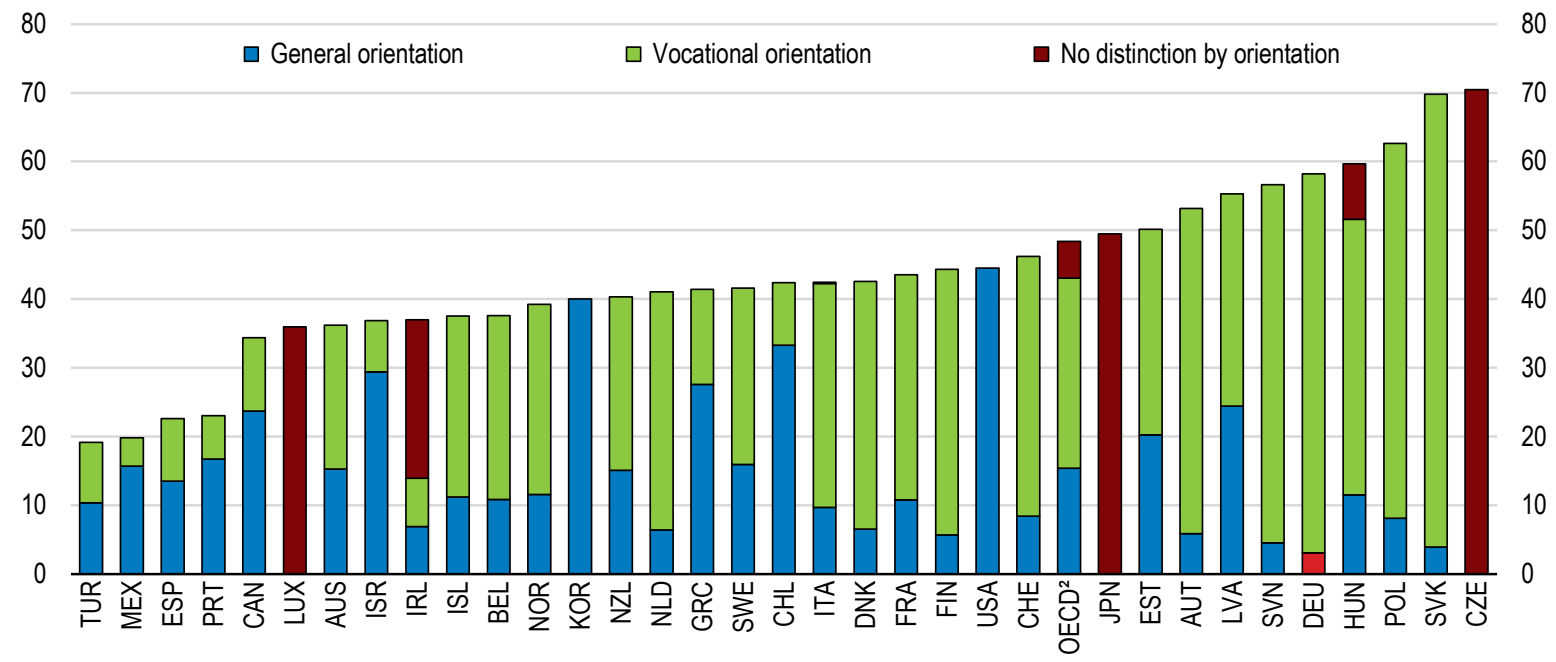

1. For Denmark, Finland, Ireland, Latvia, Luxembourg and Slovenia data for the breakdown by programme orientation are available only for 15-34 year-olds. Reference year is 2015 for Chile and Ireland.

2. Unweighted average.

Source: OECD (2017), "Education at a glance: Educational attainment and labour-force status", OECD Education Statistics (database). 
The German vocational education and training system ensures excellent integration of young people in the labour market. Employment rates for individuals with upper secondary or post-secondary non-tertiary vocational qualifications aged 25 to 34 years are as high as for individuals with a tertiary degree $\left(86 \%\right.$ and $87 \%$ respectively) $\left(\right.$ OECD, $\left.2017_{[12]}\right)$. The share of young people not in employment, education or training is among the lowest in the OECD (Figure 4).

Figure 4. Most German youth are either in employment, education or in training

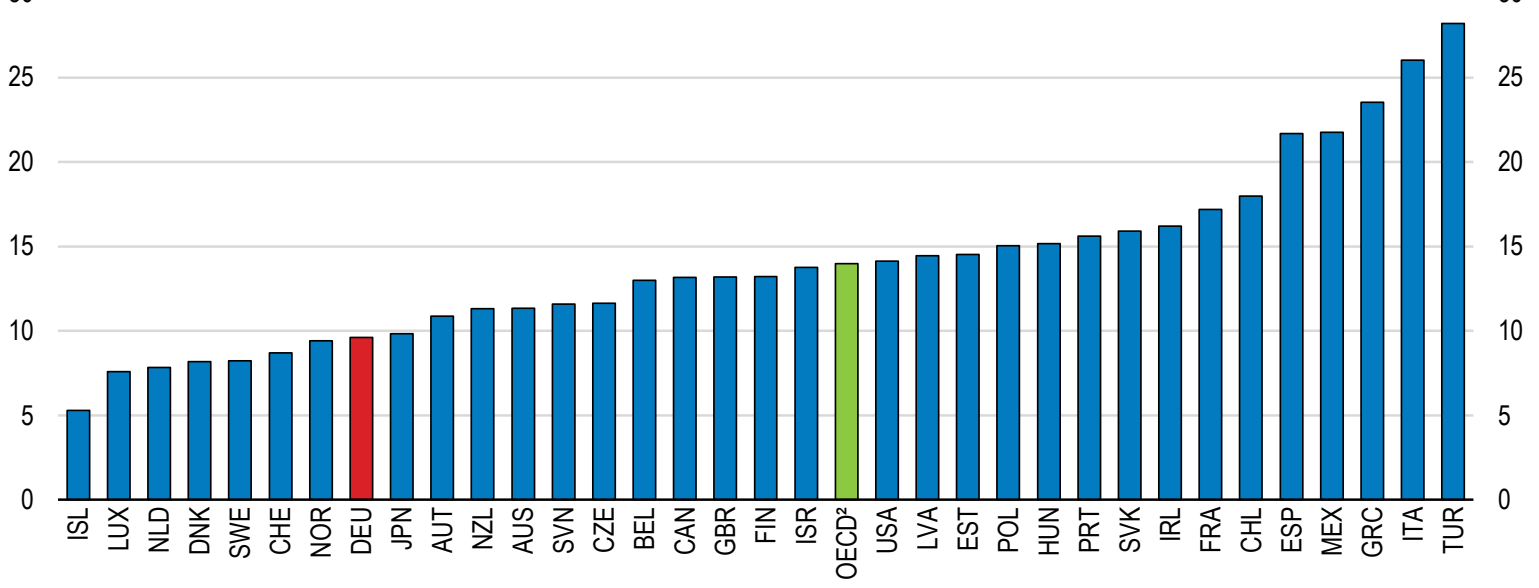

1. 2015 for Ireland and Chile. 2014 for Japan.

2. Unweighted average.

Source: OECD (2017), "Education at a glance: Educational attainment and labour-force status", $O E C D$ Education Statistics (database).

StatLink 제패 http://dx.doi.org/10.1787/888933737172

Over the past 40 years, unemployment rates between the main education levels have drifted apart (Figure 5), in particular at times of rising unemployment, showing that skills have become more important to make workers resilient. More recently, over the pasts 20 years, employment in high-skill occupations has increased markedly, whereas the share of employment in middle-skill jobs has fallen, although to a lesser extent in Germany than in some other countries (Chapter 1 of the 2018 Economic Survey of Germany). At the same time wages paid for high-skill workers have risen, while they have fallen for middle and low skilled workers who are middle-aged (Figure 6), suggesting that these trends are driven by labour demand. In part they may be driven by stronger use of digital technology (Dauth et al., 2017 ${ }_{[153]}$ and Chapter 1 of the 2018 Economic Survey of Germany). 
Figure 5. Unemployment is high among the unskilled

Unemployment rates by qualification

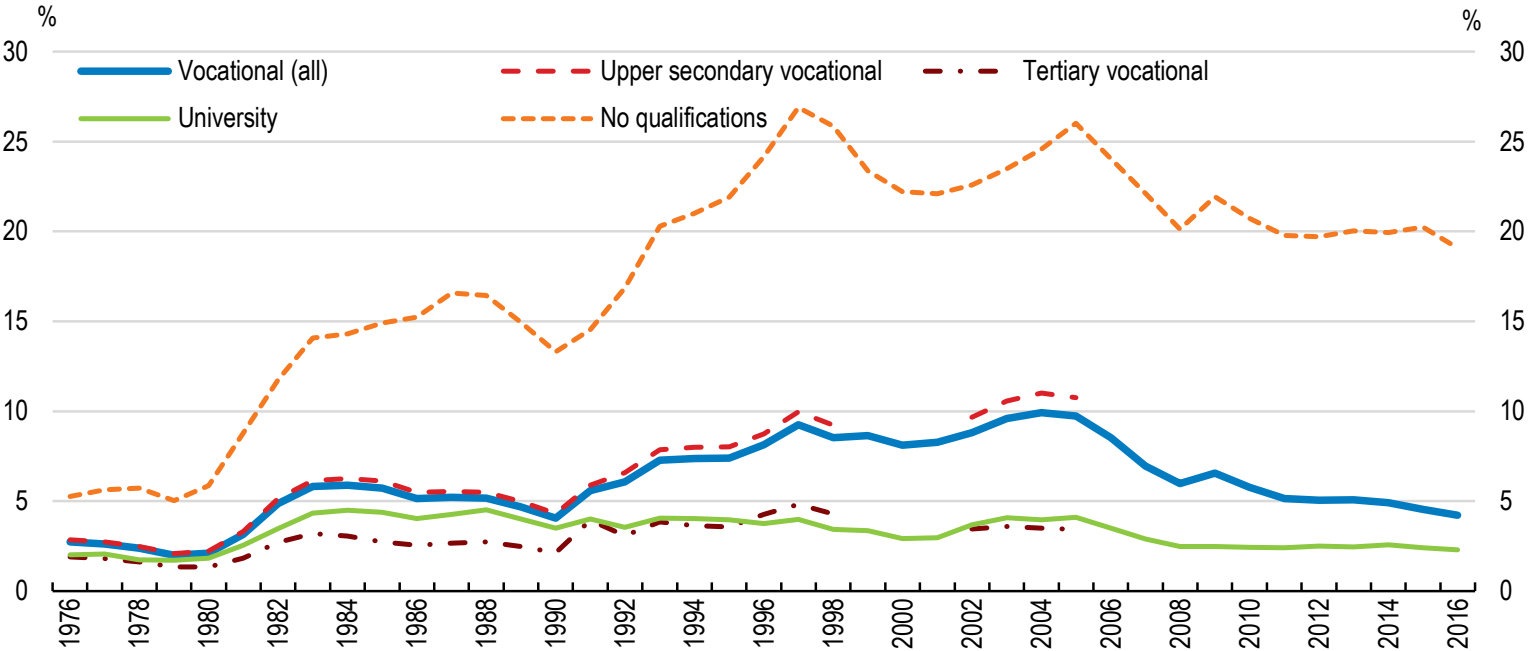

Note: Registered unemployment. Data until 1990 cover West Germany. Data from 1991 cover Germany. Source: Hausner, Karl Heinz; Söhnlein, Doris; Weber, Brigitte; Weber, Enzo (2015), Qualifikation und Arbeitsmarkt: Bessere Chancen mit mehr Bildung. IAB-Kurzbericht, 11/2015. Röttger, Christof; Weber, Brigitte; Weber, Enzo (2017), Qualifikationsspezifische Arbeitslosenquoten. Aktuelle Daten und Indikatoren, IAB.

StatLink 제표 http://dx.doi.org/10.1787/888933738331

Figure 6. Real wages rose only for high-skill workers between 1990 and 2010

Real wages by qualifications, full-time male workers aged 40

$$
\begin{aligned}
& \text { Index } 1984=100 \\
& 130
\end{aligned}
$$

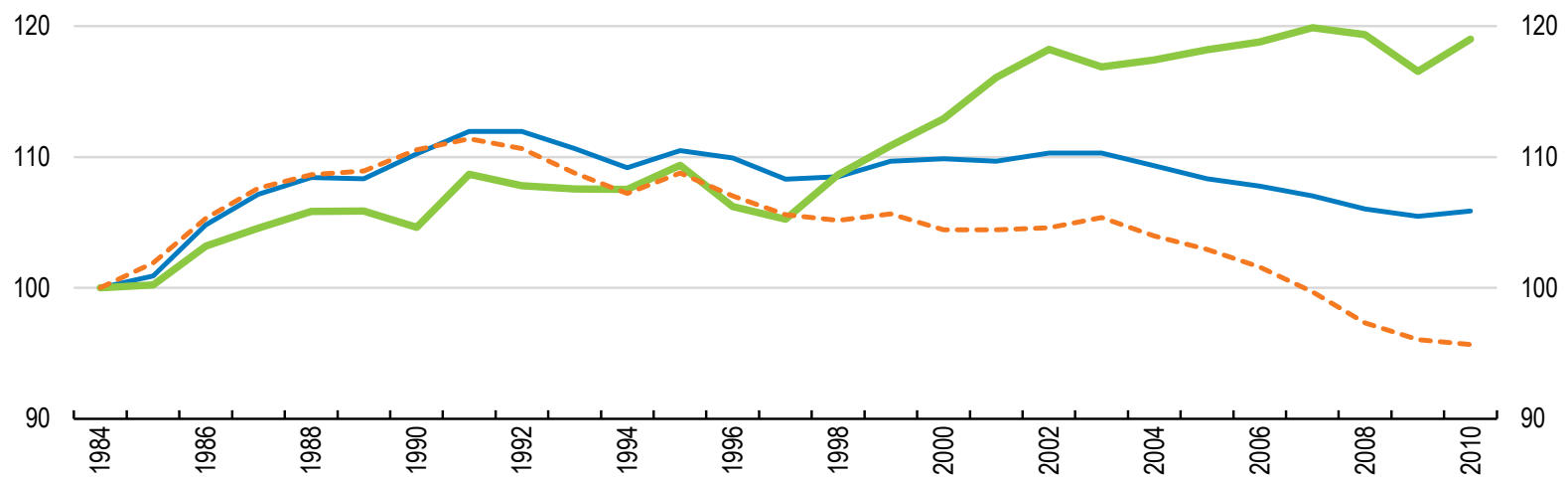

Note: Data cover West Germany.

Source: Integrated Employment Biographies (IEB) from the Institute for Employment Research of the Federal Employment Agency (IAB, Institut für Arbeitsmarkt- und Berufsforschung)

StatLink הills http://dx.doi.org/10.1787/888933738350

Germany specialises in many technologically advanced industries, including high- and medium/high-tech manufacturing and complex business services, such as research and development or computer and related activities (OECD, 2017 $[13])$. This specialisation 
pattern is supported by the country's strong advantage in high-end science, technology, engineering and mathematics (STEM) education. About 35\% of all tertiary-educated adults have a degree in a STEM field, the highest in the OECD. The share is even somewhat higher among recent graduates. At vocational upper secondary level, a third of graduates have studied engineering, manufacturing or construction-related professions. However, women are under-represented in most of the STEM fields, both at the upper secondary and at the tertiary level, where they are only $28 \%$ of new entrants. PIAAC data also shows that German workers perform STEM tasks more often than in most OECD countries (OECD, $\left.2017_{[13]}\right)$. Unlike in many advanced OECD economies, German manufacturing is strongly integrated in global value chains, yet manufacturing employment has increased since 2010 (OECD, 2017 $[14])$.

\section{Adult cognitive skills are somewhat lower than in best-performing countries}

The average PIAAC literacy proficiency score is above the OECD average (OECD, 2016 $\left.6_{[4]}\right)$ but lower than in the best-performing countries (Figure 7). Average scores in numeracy and problem-solving skills in a technology-rich environment compare more favourably. Still, outcomes lag behind Nordic countries or the Netherlands. However, most recent PIAAC results for Germany are from 2012. Adult cognitive skills are likely to be improving, as youth with stronger reading and numeracy skills leave school. PISA scores in Germany have improved over the past 15 years, more so than in many other OECD countries.

\section{Figure 7. Adult skills are above OECD average, but lower than in leading OECD countries, especially in literacy}

Mean proficiency scores in literacy and numeracy, and the percentage of adults scoring at level 2 or 3 in problem solving in technology-rich environments, 15-65 year-olds, 2012
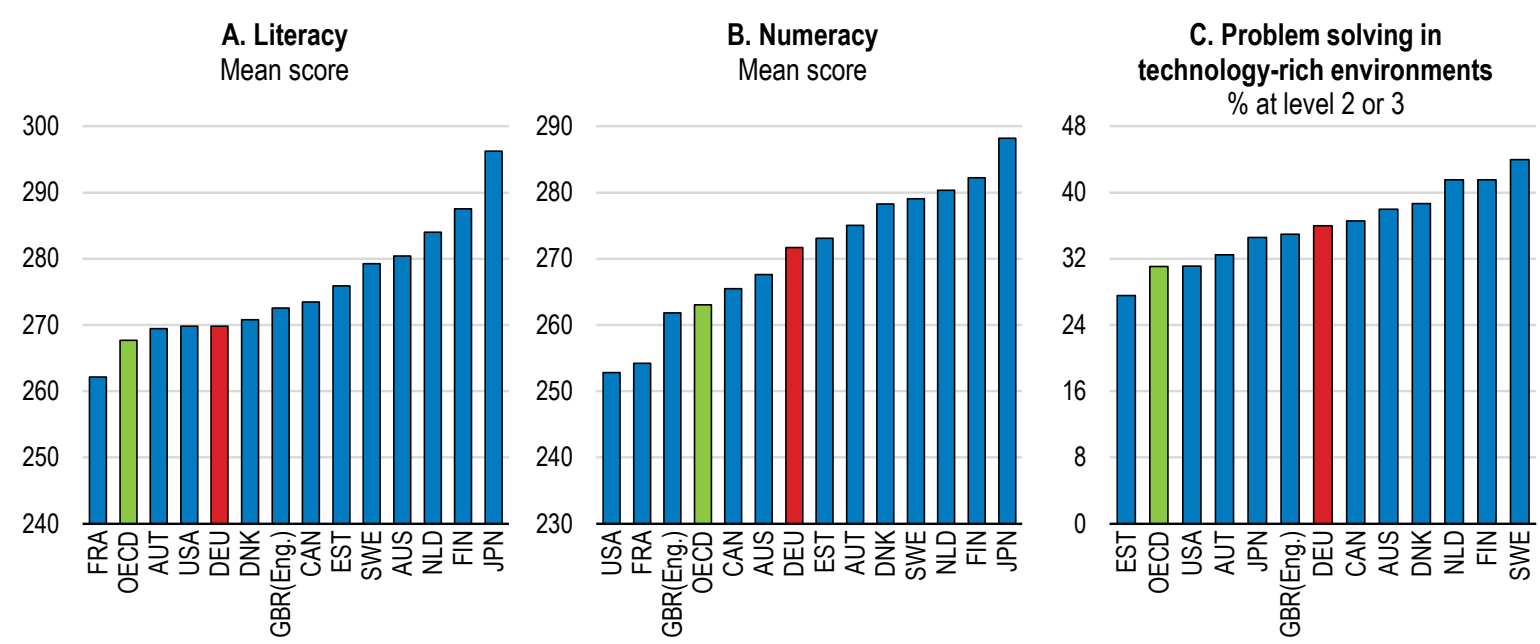

Note: France did not participate in the problem solving in technology-rich environments assessment. Source: OECD (2016), Skills Matter: Further Results from the Survey of Adult Skills.

StatLink 세대 http://dx.doi.org/10.1787/888933737761

Proficiency is relatively weak among adults with low (below-upper secondary) educational attainment. It is slightly above OECD average for adults with higher education but slightly below OECD average for adults with middle (upper secondary) education (Figure 8). In Germany, workers who have been educated to the upper secondary level have mostly gone through the vocational education system. 
Figure 8. Performance gaps with respect to leading countries are larger for adults with low and intermediate educational attainment

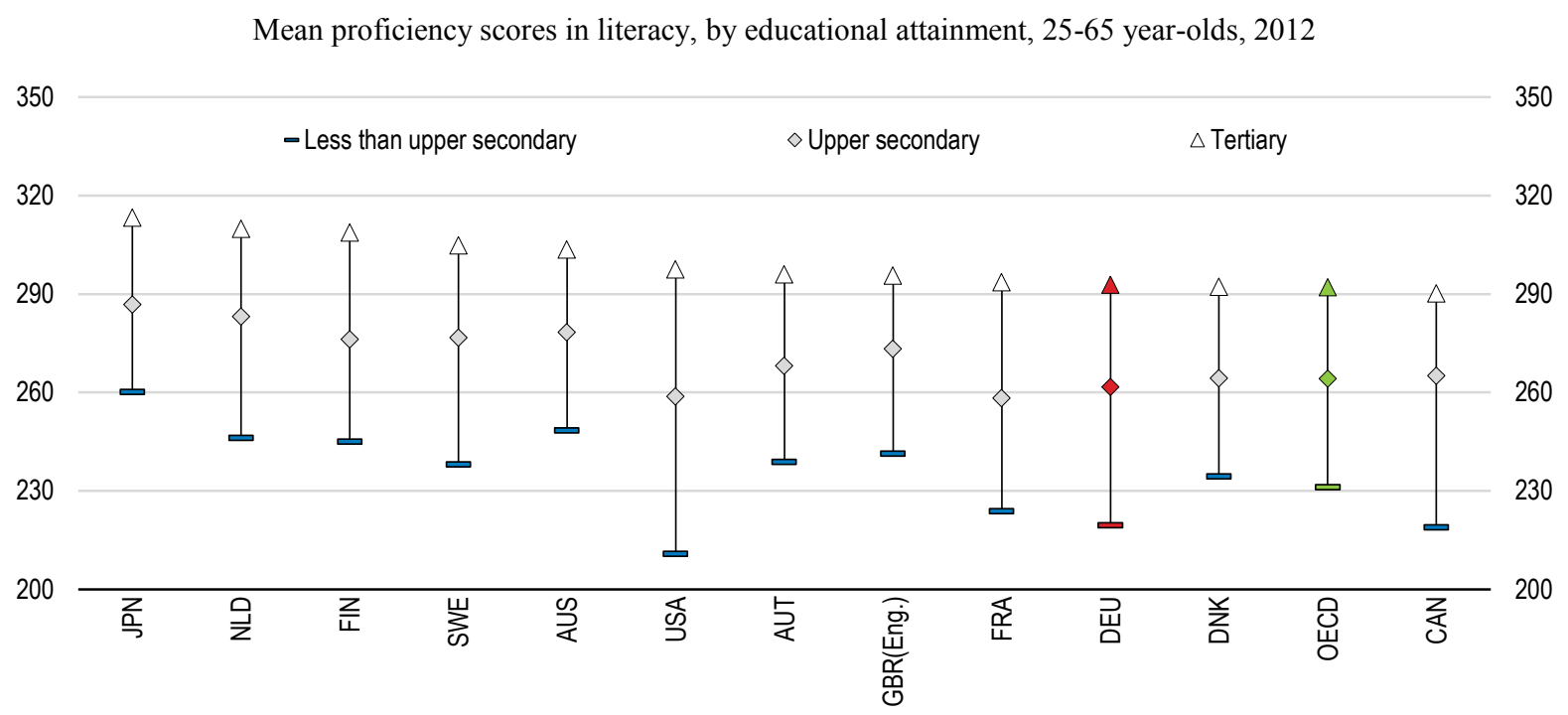

Source: OECD (2016), Skills Matter: Further Results from the Survey of Adult Skills.

StatLink त्ञाI ht htp://dx.doi.org/10.1787/888933737780

The variably of proficiency of literacy and numeracy scores is wide. Countries with the highest average scores tend to have less variability, as they are more successful in limiting the number of adults with low cognitive skills (Figure 9). A German study on functional illiteracy suggests that $15 \%$ of the German population have insufficient literacy skills to understand a full text or deal with every-day literacy requirements. Most of them are employed, have intermediate upper secondary vocational qualifications and speak German as mother tongue. They are broadly evenly distributed across age groups (Bundesinstitut für Berusbildung, 2017 $[15])$.

Eurostat's 2017 Digital Skills Survey sheds additional light on adult digital skills. The Survey measures skills based on a self-assessment of selected activities related to internet or software use. Only around $40 \%$ of prime-age Germans had above basic skills enabling them to be more active in the use of information and communication technologies (ICT), well below top-performing countries (Figure 10).

Workers in Germany carry out tasks independently and plan their own work on the job more frequently than in other OECD countries. However, they are less likely to perform managing, communicating and marketing tasks. They also show a lower readiness to learn than on average in OECD countries (Grundke et al., 2017 $\left.{ }_{[16]}\right)$. Where workers specialise in marketing and accounting or management and communication tasks (and thus require the corresponding skills), they are more closely integrated in GVCs through their production $($ OECD, 2017 $[13])$. These skills are also in high demand by employers. In view of the increasing complementarity of services and manufacturing these skills may need further development. 
Figure 9. Dispersion of adult cognitive skills is large

Average and variability of PIAAC numeracy scores, 25-65 year-olds, 2012

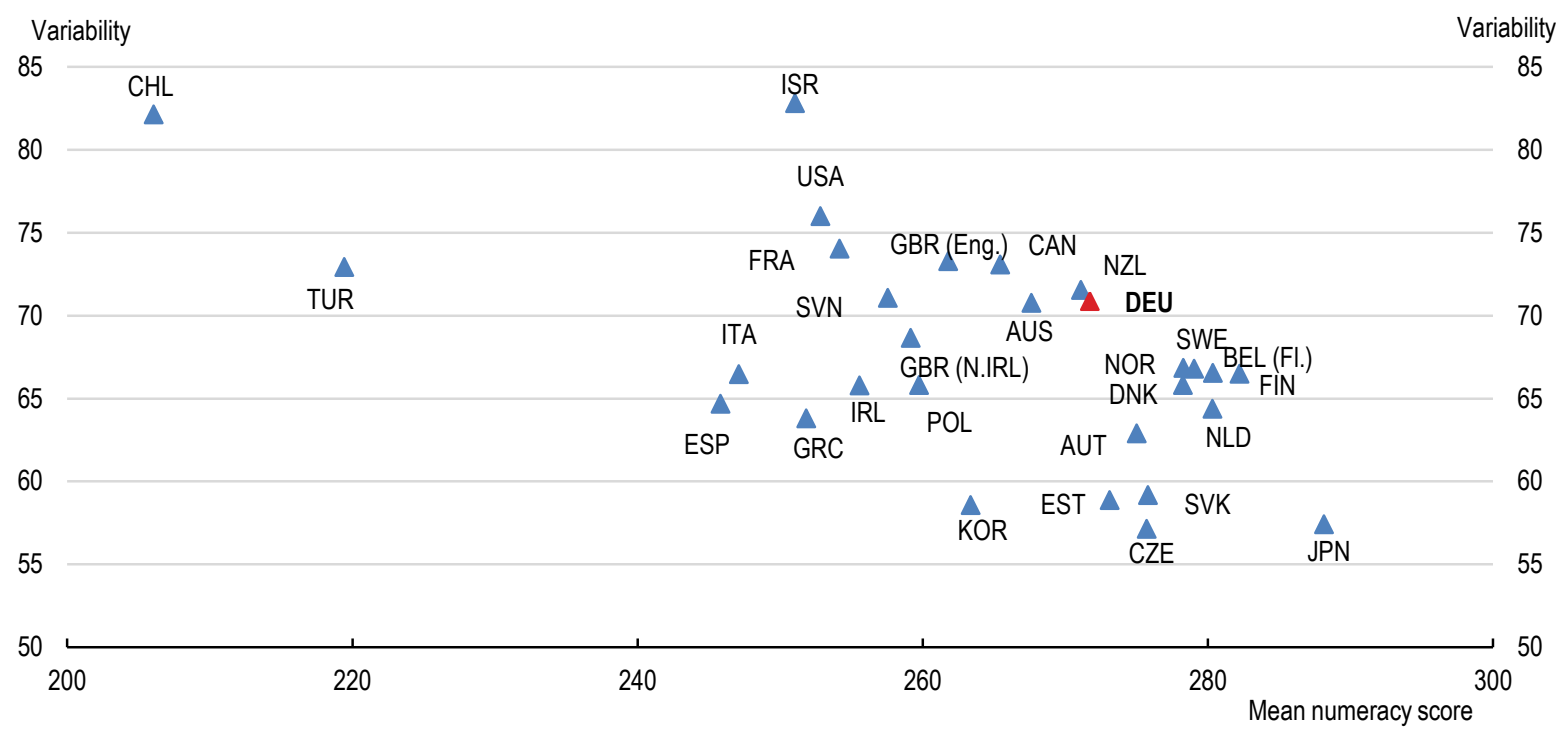

Note: The measure of variability used is the interquartile range (difference between the third quartile minus first quartile).

Source: OECD (2016), Skills Matter: Further Results from the Survey of Adult Skills.

StatLink 세매 http://dx.doi.org/10.1787/888933738369

Figure 10. ICT skills are lower than in leading countries, especially among the young

The share of population with above basic ICT skills, by age cohort, 2017

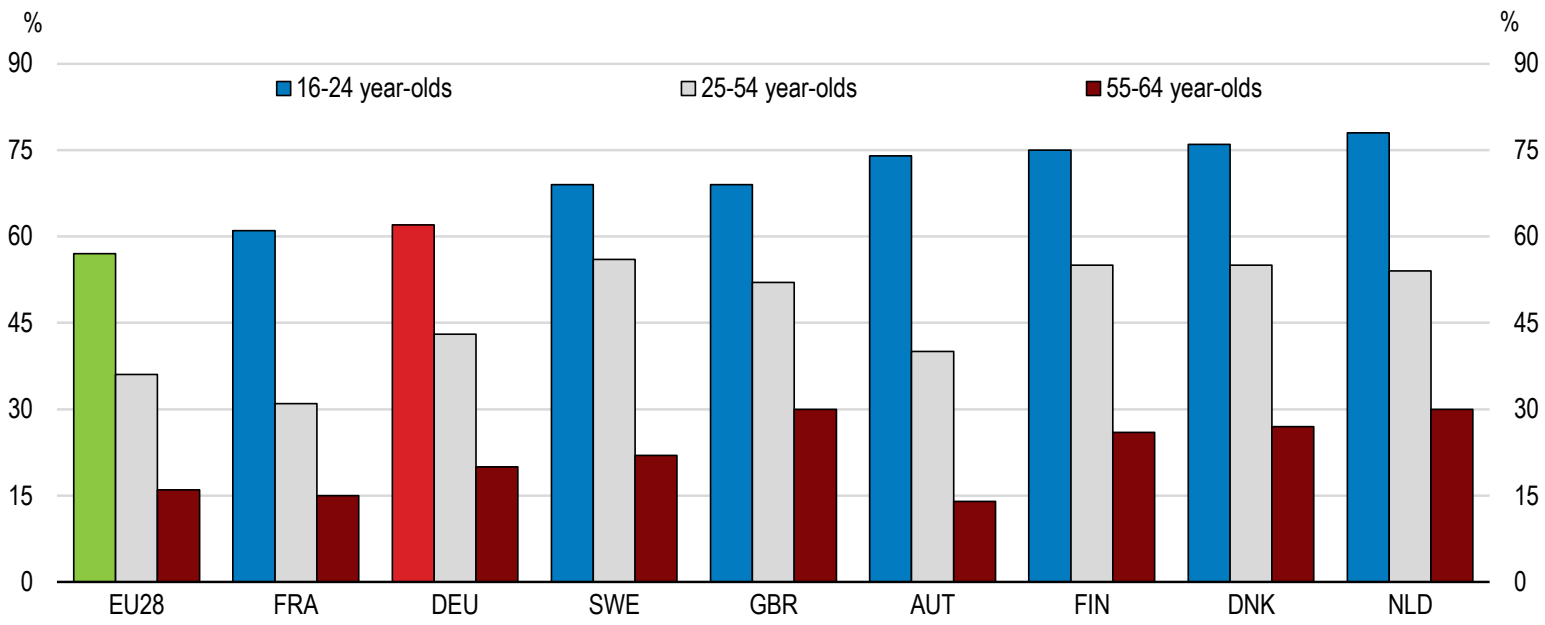

Source: Eurostat (2018), Individuals' level of digital skills (database).

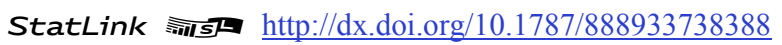

\section{Improving the matching of worker skills to jobs could boost productivity}

The PIAAC study distinguishes field-of-study mismatch, qualification mismatch and skill mismatch (Box 3). Field-of-study mismatch in Germany is among the lowest in the OECD. This is likely to reflect strong work-based training in vocational education, which allows many vocational education graduates to continue working with the same employer after 
completing their degree. Strong supply and demand of STEM skills also contributes. A well-developed system of career counselling for young people may also help. Vocational counselling and orientation for young people start about two years before pupils finish upper secondary school. Career and study orientation is part of education in all schools.

\section{Box 3. Skill mismatch measures in the OECD PIAAC study}

Qualifications mismatch arises when workers have an educational attainment that is higher or lower than that required for their job. This is assessed in relation to workers' answer to the question about the usual qualifications, if any, "that someone would need to get (their) type of job if applying today". The answer to this question is used as each worker's qualifications requirement and compared to their actual qualifications to identify mismatch.

Field-of-study mismatch occurs when workers are employed in a different field from that in which they have specialised. The matching is based on a list of occupations (at the 3-digit ISCO classification) that are considered as an appropriate match for each field of study.

Skills mismatch arises when workers have higher or lower information processing skills proficiency (such as in literacy or numeracy) than required for their job. To assess skill proficiency requirements for a job, workers were asked whether they feel that they "have the skills to cope with more demanding duties than those they are required to perform in their current job" and whether they feel they "need further training to cope well with their present duties". Workers are classified as well matched in a domain if their proficiency score is between some minimum and maximum score observed among workers who answered "no" to both questions in the same occupation and country. In the PIAAC study, workers are overskilled in a domain if their score is higher than the 95th percentile of self-reported wellmatched workers; they are under-skilled in a domain if their score is lower than the 5th percentile of self-reported well-matched workers. It should be noted that the PIAAC study does not measure all forms of skills mismatch it focuses on information processing skills in the domains assessed but, for example, leaves out mismatch related to job-specific skills or that involve generic skills.

Source: This box was taken from the 2017 OECD Economic Survey of New Zealand

While underqualification is also low in international comparison, overqualification is relatively high (Figure 11). These results also emerge on the basis of survey evidence, in which workers themselves assess how well their skills are matched to their jobs. Overqualification is more widespread among workers with middle qualifications (upper secondary education (CEDEFOP, $\left.2017_{[17]}\right)$. This could perhaps reflect workers with middle qualifications replacing workers with low qualifications on jobs with low skill demands. Overqualification has a strong negative impact on hourly wages, estimated to be close to $15 \%$ in Germany $\left(\mathrm{OECD}, 2016_{[4]}\right)$. Being foreign-born or on a temporary contract increase the probability of overqualification by 10 percentage points. Improving the match of worker skills with job requirements can boost productivity substantially. Reducing skill mismatch to the lowest levels in each industry across countries which have participated in the PIAAC study would boost the level of productivity by $6 \%$ (Figure 12). 
Figure 11. Field-of-study mismatch is low but overqualification is above the OECD average

Percentage of mismatched workers, by type of mismatch, 2012 and $2015^{1}$

\section{A. Qualification mismatch}

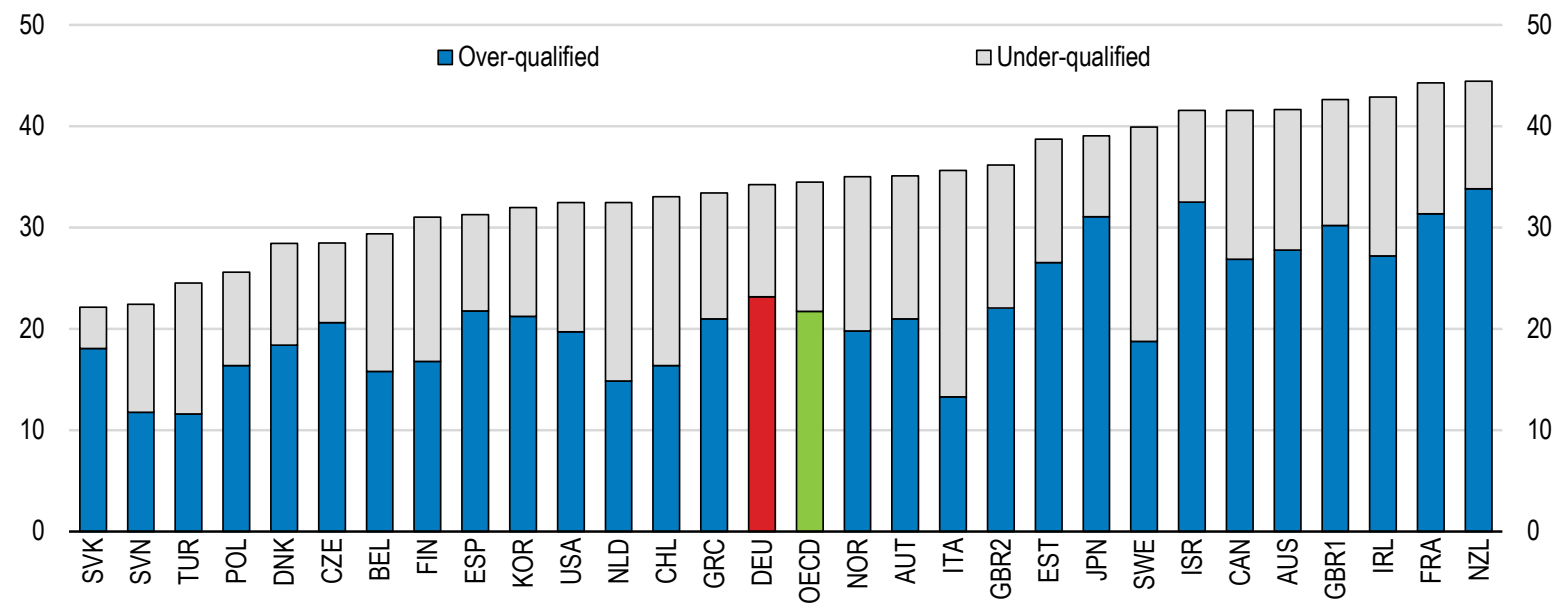

\section{B. Field-of-study mismatch}

60

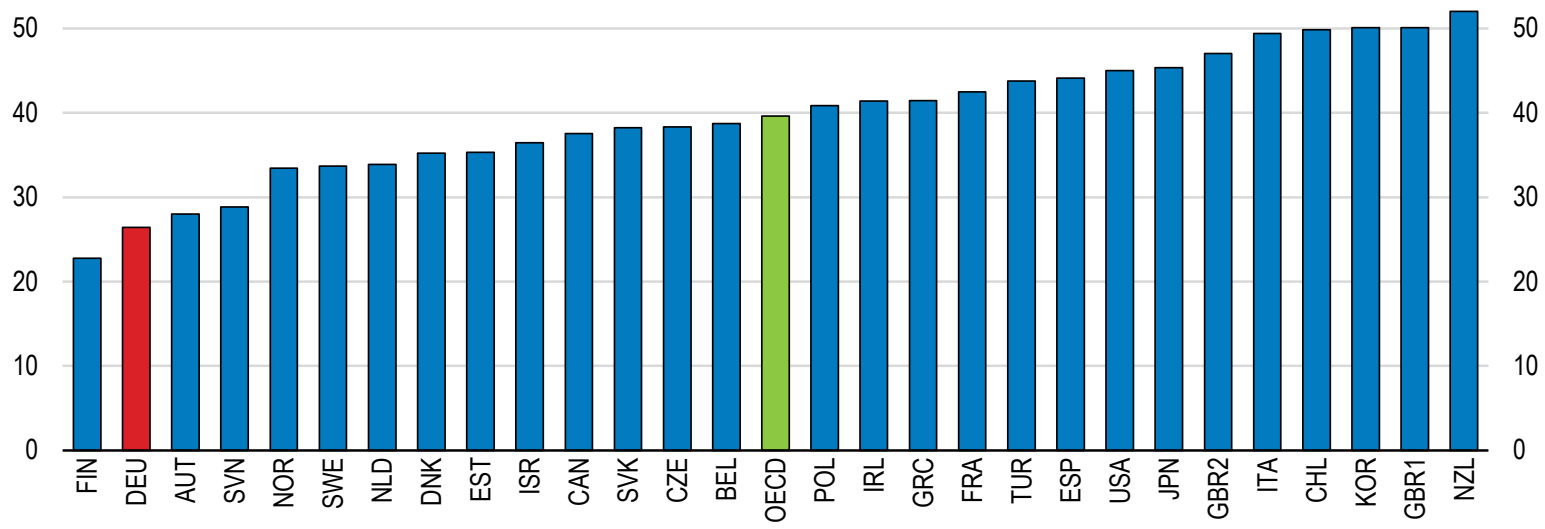

Note: Qualifications mismatch occurs when a worker has a higher or lower level of qualification than is required for his/her job. Field-of-study mismatch occurs when a worker has a qualification in a different field than required for his/her job.

1. Data correspond to 2015 for countries participating in the second round of the Survey of Adult Skills: Chile, Greece, Israel, New Zealand, Slovenia and Turkey. For other countries, data correspond to 2012 based on the first round of the Survey of Adult Skills. Data indicated as Belgium correspond to Flanders; GBR1 = England and GBR2 = Northern Ireland.

Source: OECD (2016), Skills Matter: Further Results from the Survey of Adult Skills. 
Figure 12. Reducing mismatch boosts productivity

Simulated gains to allocative efficiency from lowering skill mismatch to the best practice

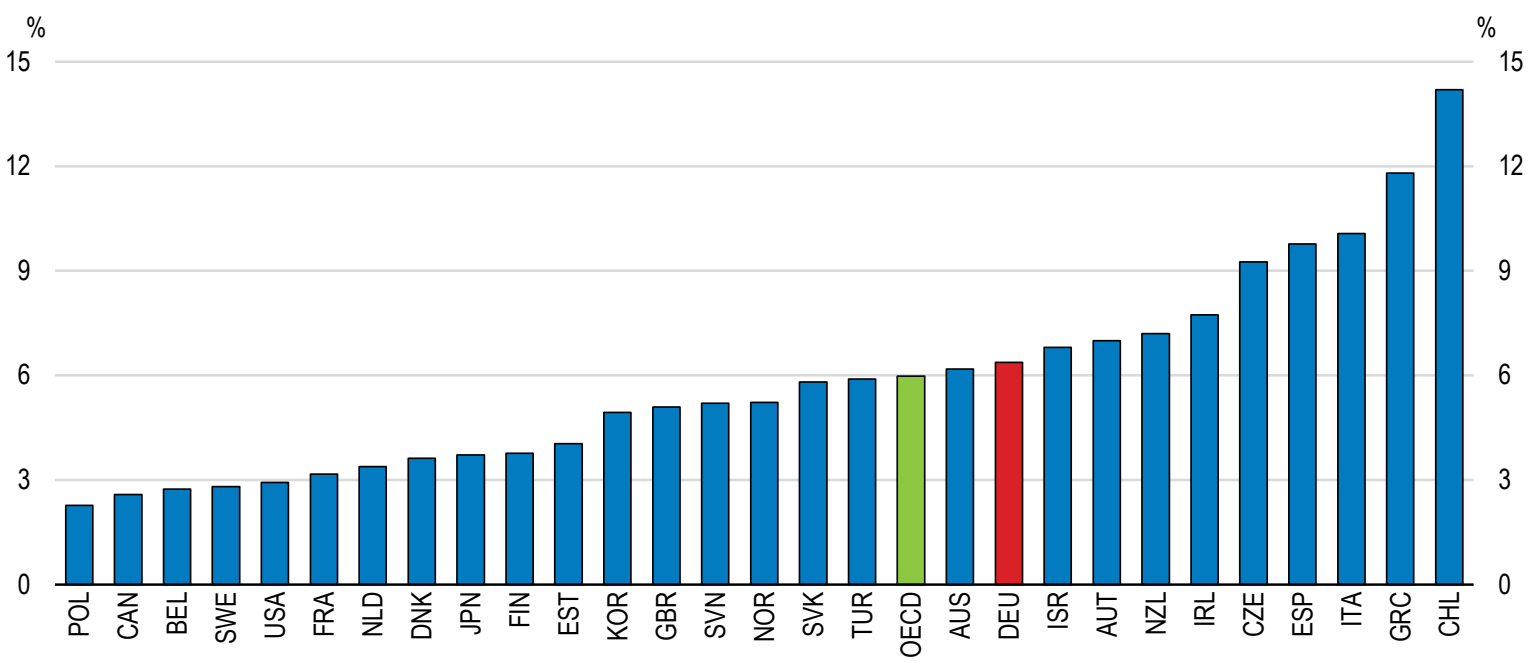

Note: The chart shows the difference between the actual allocative efficiency and a counterfactual outcome based on lowering the skills mismatch in each country to the best practice. Mismatch indicators are aggregated for 11 market industries using a common set of weights based on the industry employment shares for the United States. Skills mismatch is captured using the 2012 and 2015 waves of PIAAC data.

Source: Adalet McGowan, M. and D. Andrews (2017), "Skills mismatch, productivity and policies: Evidence from the second wave of PIAAC", OECD Economics Department Working Papers, No. 1403.

StatLink 제으 http://dx.doi.org/10.1787/888933738426

\section{Gender inequality contributes to mismatch}

Broad gender equity in educational attainment contrasts with the large earnings gap between men and women. This difference is more marked between highly educated men and women. Full-time working women with tertiary education earn about $70 \%$ of what men earn (Figure 13). The earnings gap is even bigger when hours worked are taken into account. In $2015,47 \%$ of all women in employment were working part-time, while this was the case for only $9 \%$ of men. About $72.7 \%$, mothers with children under the age of 18 are especially likely to work part-time. Part-time work reduces earnings not only through the reduced working time itself, but also through less experience.

Women's skills are used less then men's, and this difference is more marked than in other high-income countries with strong PIAAC results (Figure 14, unadjusted results). A large part of this difference can be attributed to the different incidence of part-time work and occupational choice. Gender differences in skill use are much lower after controlling for these variables (Figure 14, adjusted results). Indeed, part-time workers are $25 \%$ more likely to be overqualified than full-time workers in Germany (OECD, 2016 $[4]$ ). This makes parttime employment among women a major cause of overqualification, explaining about a third of the total incidence. Part-time work also raises the probability of overskilling by 10 percentage points. Moreover, part-time employment among women generates poverty risks, especially following separations and in old age as argued in the 2016 Economic Survey (OECD, 2016 $[18]$ ) and by research in Germany (Bundesinstitut für Bevölkerungsforschung, $\left.2017_{[19]}\right)$ ). 
Most women state that they work part-time voluntarily. However, their decisions are influenced by the incentives in the tax system and the availability of childcare and full-day schooling. Indeed, in a tight labour market, with particularly low unemployment rates for qualified workers, addressing barriers to full-time employment and broadening barriers to occupational choice of women could boost productivity and wages for women. As argued in previous Economic Surveys $\left(\mathrm{OECD}, 2016_{[18]}\right)$, steps to lower the taxation of second earners, who are often women, would boost their incentives to work longer hours. Expanding the provision of full-day formal childcare and primary education would also help.

There are large differences in the proportion of men and women across professions, as in many other countries. Professions in which women are more strongly represented tend to pay less. One explanation is that jobs which offer better compatibility, in terms of working time, with family life offer lower wages. More working time flexibility is typically associated with higher female participation (Wrohlich and Zucco, 2017 ${ }_{[20]}$ ). Jobs offering part-time work options and flexibility are in high demand among many women, which lowers the wage (Haan, Hammerschmid and Rowold, 2017[21])).

Figure 13. The earnings gap between men and women is particularly large among highly educated workers

Women's earnings as a percentage of men's earnings, by educational attainment, 25-64 year-olds with income from full-time employment, 2014

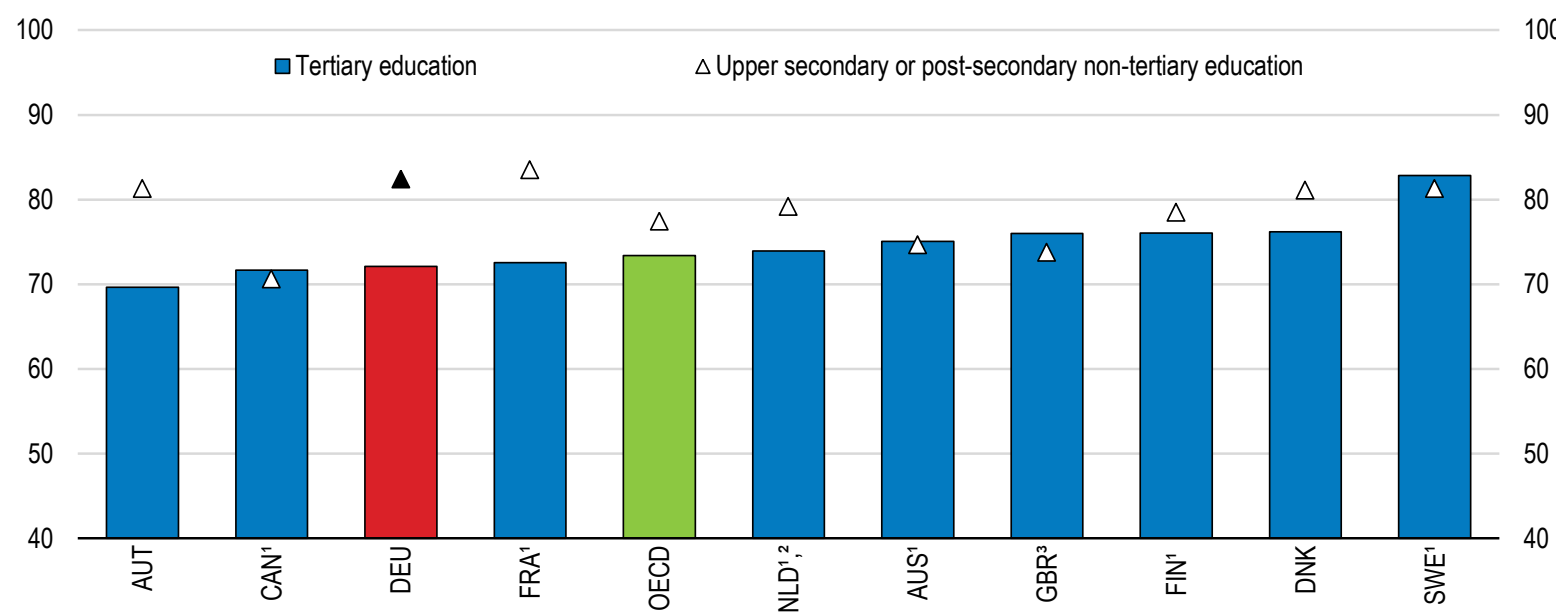

1. 2010 for the Netherlands. 2012 for Australia, France and Sweden. 2013 for Canada and Finland.

2. Educational attainment levels are based on the ISCED-97 classification.

3. Data for upper secondary attainment include completion of a sufficient volume and standard of programmes that would be classified individually as completion of intermediate upper secondary programmes (18\% of the adults are under this group).

Source: OECD (2016), Education at a Glance 2016: OECD Indicators.

StatLink त्ञाI

Take-up of parental leave influences the distribution of home and childcare responsibilities between women and men. Since 2007 parents of young children can receive a parental leave cash benefit amounting to $65 \%$ of previous net earnings, subject to a ceiling. It can be drawn either by the father or the mother for a maximum of 12 months, if they temporarily stop working to look after their children. If the second parent takes at least 2 further months off work to look after a child, the total duration for the couple is 14 months. Since 2015, 
parental leave has become more flexible, allowing parents to combine part-time work with parental leave benefits at reduced rates. Parents may receive an additional four months of parental leave benefits if they choose to simultaneously work between 25 and 30 hours per week during that time.

Figure 14. Women's skills are used less than men's

Gender differences in the mean use of information-processing skills at work (men minus women), \% of the mean use of skills by women, 2012
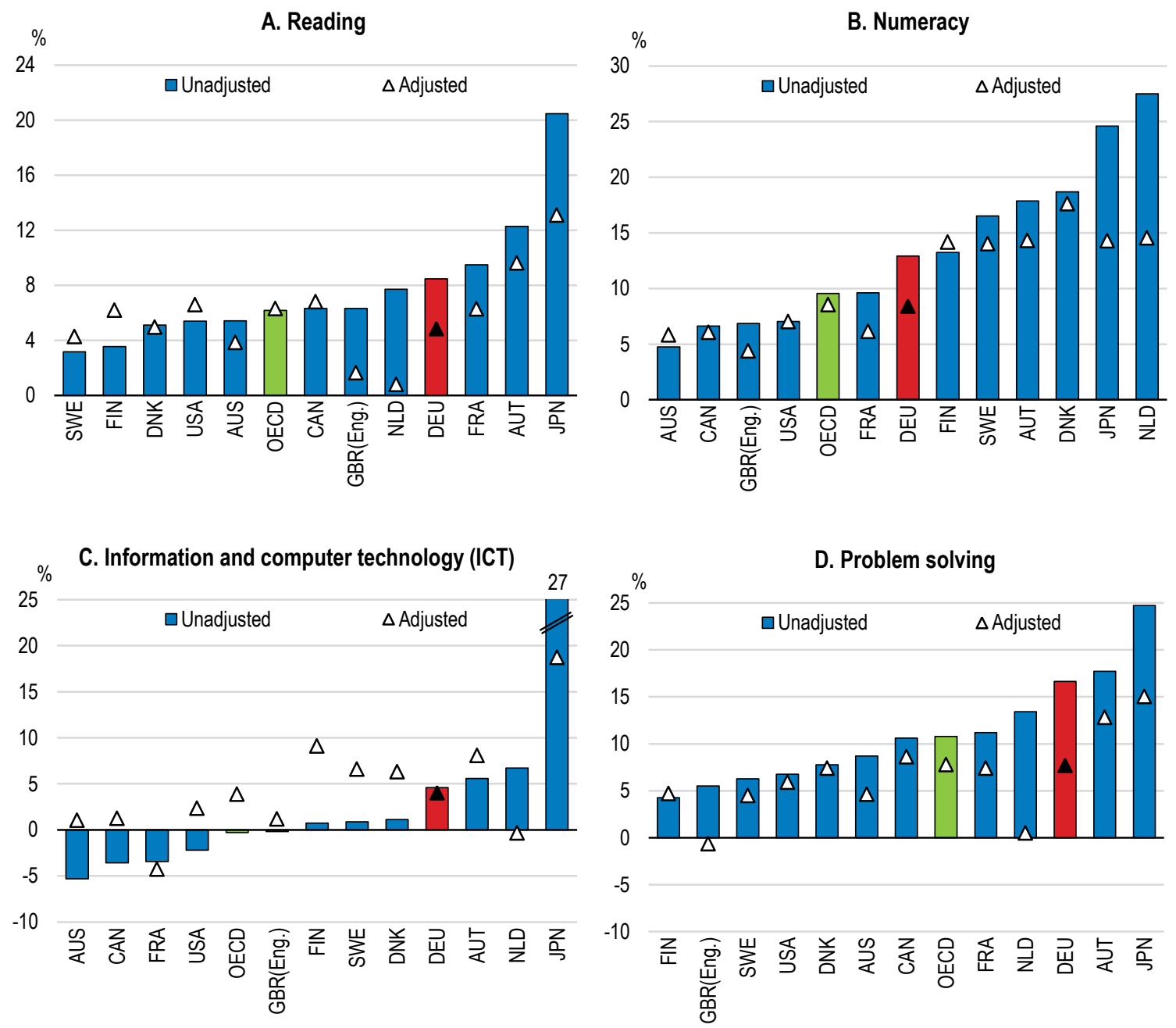

Note: Adjusted estimates are based on ordinary least squares (OLS) regressions including controls for literacy and numeracy proficiency scores, hours worked, and occupation dummies based on the International Standard Classification of Occupations (ISCO, 1-digit).

Source: OECD (2016), Skills Matter: Further Results from the Survey of Adult Skills.

StatLink 세에 http://dx.doi.org/10.1787/888933737875

These entitlement rules have provided incentives for fathers to take some parental leave. Moreover, it has resulted in a substantial reduction in the prevalence of social norms according to which it is the women who are expected to look after children and home rather than their careers. As a result of the introduction of this benefit, the share of fathers who took at least two months of parental leave increased sharply from less than $3 \%$ in 2006 to 
$34 \%$ ten years later (Unterhofer and Wrohlich, 2017 ${ }_{[22]}$ ). Moreover, social norms have changed beyond the parents, resulting in better acceptance of mothers taking up paid fulltime employment. These social norms have in turn influenced female labour supply behaviour. However, mothers generally take 12 months of leave whereas fathers often take only 2 months and often at the same time as the mothers (Unterhofer and Wrohlich, $2017_{[22]}$. These findings suggest that requiring fathers to take more parental leave for the couple to benefit from the maximum joint allowance would result in further benefits in terms of reducing gender stereotypes, earlier return and stronger labour market participation by women, and better skills use.

\section{Removing geographical barriers to mobility can reduce mismatch}

Rental prices have increased strongly in major urban centers over the past decade, whereas low and middle incomes have not. Housing construction in many rural areas, where population in some cases falls, has been stronger than what demographic trends would require, resulting in vacant stocks of older housing. Housing supply does not keep pace with rising population in urban areas (Philipp Deschermeier et al., 2017[23]). High housing costs prevent people from moving into economically successful, highly productive urban areas. Such barriers can reduce national GDP by considerable margins (OECD, 2017[24]). Planning restrictions that prevent densification are particularly costly, as there is a negative relationship between a region's developed area per capita and its economic growth.

Densification of urban and sub-urban residential areas and adapting land use regulation accordingly can improve housing supply (OECD, 2017 $\left.{ }_{[24]}\right)$. Federal planning law does not hinder densification. Soil protection and densification are general planning principles. Federal legislation states that urban development is to primarily take place through measures of inner urban development. However, it is the Länder and municipal governments which set specific zoning regulations. The federal government does not monitor municipal zoning regulation as it would be incompatible with the German constitution.

Restrictive zoning regulations and planning decisions can limit the possibilities for densification in many cities. They include explicit density restrictions (for example through floor-to-area ratios) and implicit density restrictions (for example minimum lot-size requirements and restrictions on multi-family homes), although generally these may be exceeded provided the general requirements on healthy conditions are safeguarded. The municipality can also waive restrictions, or change plans. Easing density restrictions is most important in low-density areas close to city centres and along public transport corridors, but gradual densification should be permitted throughout most parts of an urban area. More proactive policies to foster densification can include incentives for compact development on brownfield sites (OECD, 2015[25]).

Higher urban density results in more proximity between businesses and people's homes, which promotes sustainable transport, like walking or cycling. This in turn promotes health and results in lower $\mathrm{CO} 2$ emissions. Transport-related urban emissions are much lower in compact cities, such as Shanghai and Barcelona, (OECD, 2015 $\left.5_{[25]}\right)$. Higher urban density also limits the loss of natural habitat and biodiversity through urban sprawl, which is one of the major environmental policy challenges in Germany according to the German Federal Environment Agency.

Germany has boosted mobility with a relocation subsidy for unemployed workers who accept a job in a distant location. This scheme has improved the stability of employment and pay in the newly found job among workers who benefited from the subsidy, as a result 
of a better match between worker and job (Caliendo, Künn and Mahlstedt, 2017[26]). However, entitlement rules to social assistance transfers prevent young people from moving out of their parents' home, as below 25-year-olds cannot claim such benefits, which may impede mobility. Moreover housing benefits for low-income households prevent relocation, because benefit recipients cannot move to housing that is more expensive. (Sachverständigenrat, 2017 $[8]$ ). The coalition agreement foresees more funding for social housing, which could make it easier for workers to move to dynamic urban centers.

The new government plans to give financial support to families with children who build or buy their own private homes (up to EUR 1200 per child for ten years subject to an income ceiling of EUR 75 000, or higher for families with children). However, this measure risks pushing up prices in urban areas. The measure may therefore result in more construction in thinly populated areas, which could be counterproductive with respect to densification (Michelsen, 2018 $\left.{ }_{[27]}\right)$. The subsidy is not targeted at low-income households and has a high budgetary cost (EUR 22 billion over ten years). Moreover OECD research with crosscountry data has shown that the impact of subsidies for owner-occupied housing on prices may even reduce access to housing for low income households (Andrews, Caldera Sánchez and Johansson, $2011_{[28]}$ ). Whether prices in urban areas increase depends on the supply of construction sites. The government, plans complementary measures to increase the amount of construction sites especially in urban areas. The coalition agreement also includes a commitment to higher spending for the construction of social housing.

\section{Inclusiveness has improved but more progress would boost skills}

Education and socio-economic background is strongly transmitted between generations. Adults with a parent with a higher education background score more than 50 points (equivalent to about 3.5 years of full-time education) higher than adults with unskilled parents (Figure 15, unadjusted impact). This difference is even larger among young adults (age 25-34 years; results not shown). In Sweden, for example, this difference amounts to 30 points (equivalent to 2 years of education). In the case of Germany, much of this transmission can be explained by educational attainment, immigrant status, and other socioeconomic variables. After removing the impacts of these variables, the impact of parental education background is lower (Figure 15, adjusted impact). The impact of parental educational background on adult cognitive skills appears to be transmitted through its influence of parental educational attainment to the educational attainment of their children.

Upward mobility through education pathways has improved only slowly (OECD, 2017 $7_{[12]}$ ). About $13 \%$ of $45-59$ year-olds whose parents did not attain tertiary education have attained an academic tertiary qualification themselves. Among 30-44 year-olds, the figure is almost the same, at $14 \%$. Another $11 \%$ have attained a vocational tertiary qualification. The percentage of migrants attaining a higher education entrance qualification increased substantially among younger age groups. There is nonetheless still a marked gap relative to people without migrant backgrounds.

The risk of failing to get an upper secondary degree is also much higher for individuals whose parents have immigrated and have low education background, and this difference is much bigger than in most countries, notably Canada, Denmark or France. Very few youth with immigration background whose parents have low education make it to tertiary education.

Weaker education outcomes caused by parents' low income or lack of education is a key transmission mechanism through which inequality can have a negative impact on economic 
growth and thereby reduce living standards $\left(\mathrm{OECD}, 2015_{[29]}\right)$. For example a large share of workers with weak cognitive skills contributes to the incidence of low-pay work, which is high in Germany, resulting in higher social transfers to prevent poverty.

\section{Figure 15. Low parental education is an important predictor of skills}

Differences in PIAAC literacy scores between contrast categories within various socio-demographic groups, score-point difference, 2012 and 2015

\section{A. Difference in literacy scores between individuals aged 25-65 with one parent educated to tertiary level and no parent educated to upper secondary level}

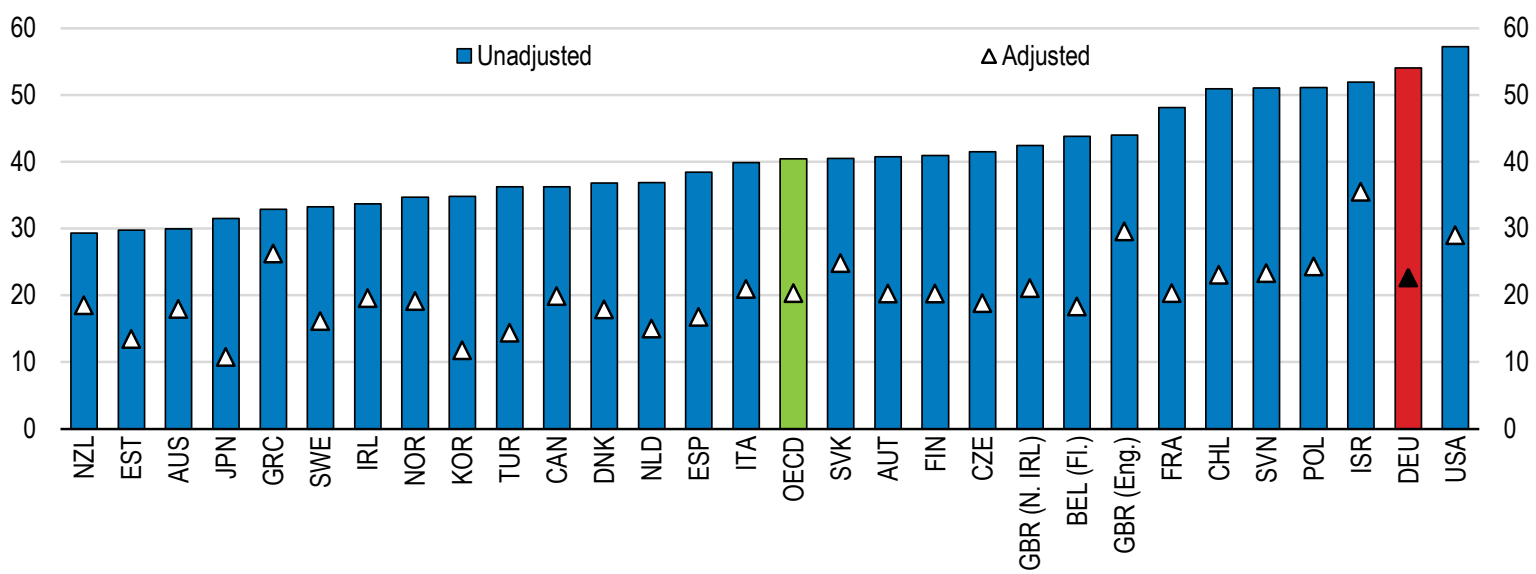

B. Difference in literacy scores between individuals with and without immigrant background ${ }^{1}$

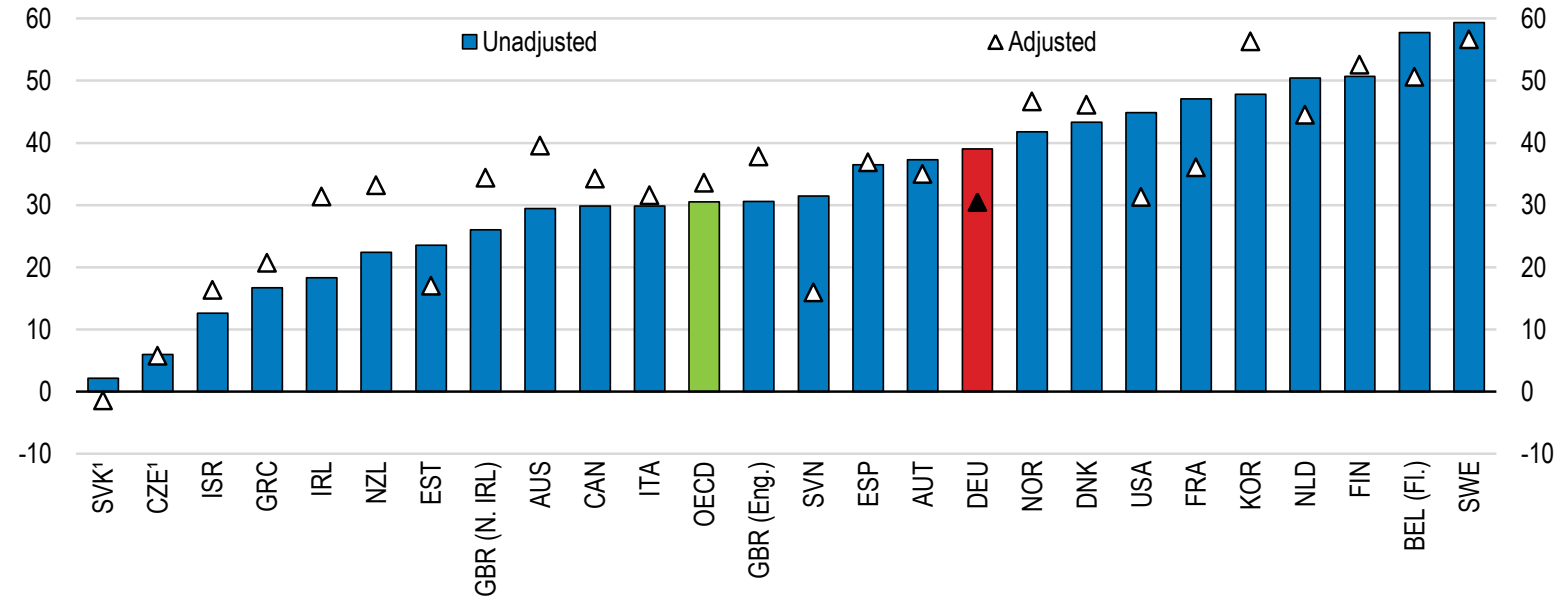

Note: Unadjusted differences are the differences between the two means for each contrast category. Adjusted differences are based on a regression model and take account of differences associated with the following variables: age, gender, education, immigrant and language background and parents' educational attainment. 1. Individuals that are both native-born and speak a native language is compared to those who are both foreignborn and speak a foreign language as their mother tongue.

Source: OECD (2016), Skills Matter: Further Results from the Survey of Adult Skills.

\section{StatLink त्ञाज् http://dx.doi.org/10.1787/888933738445}

The intergenerational transmission of low education is reinforced by child poverty. Child poverty is significant, as in other OECD countries. In Germany it is unusually strongly concentrated among parents with low education. Child poverty in families in which the parents have middle education is also substantial. Poverty is also persistent: For $21 \%$ 
poverty lasts at least five years (Tophoven et al., 2017 $7_{[30]}$ ). Among these children $49 \%$ live with a single parent, $46 \%$ have immigration background and $37 \%$ have at least two siblings.

The economic benefits of achieving more equity in education are large. Completing university has been shown to increase the earnings of men with disadvantaged family backgrounds, including from migrant backgrounds, even more than for those from more favoured backgrounds (Perini, 2014 [31]), perhaps because motivation of talented youth from disadvantaged backgrounds is particularly strong.

Means-tested support for youth from low-income families pursuing higher education and upper secondary education from low-income families amounts to up to EUR 735, depending on family income. For students in tertiary education, half of the amount is generally provided as a grant, half as an interest-free loan. Students can earn additional income up to EUR 450 per month without any deductions. Government-sponsored loans are also available, but for most of them students have to pay $3.5 \%$ interest (" $\mathrm{KFW}$ Studienkredit') and repayments are not income-contingent.

One option to reduce the intergenerational transmission of income and improve access to higher education for youth from low-income families with low-education parents is to provide the full amount of means-tested support as a grant for these youth. Indeed, access to grants for students from the most disadvantaged backgrounds is particularly important. Families with low income and low education often underestimate the benefits of higher education, providing a case for subsidising access more strongly for them (OECD, $\left.2008_{[32]}\right)$.

Conversely, students from high income families could make a bigger contribution to the cost of higher education through the payment of university fees, which have been abolished in most Länder in recent years. Detailed empirical evidence on the impact of raising fees for study at universities, accompanied by the introduction of government-sponsored loan schemes in which repayments are tied to the level of income attained once students have graduated is available for Australia. It shows that this policy has allowed widening access to university education by mobilising private funds, while the higher fees did not alter the composition of the studentship to the disadvantage of students with modest socio-economic background (Chapman, 2006 [33]).

\section{Education outcomes of disadvantaged youth have improved strongly but early tracking may still hinder equity}

Progress has been made in improving education outcomes of youth at school, including those with poor socio-economic background, since the PISA study in 2006. For example, the share of 15-year-old pupils with weak socio-economic background who were resilient in their proficiency rose from $25 \%$ to $32 \%$ between 2006 and 2015 (Figure 16), a bigger improvement than in most OECD countries. Pupils' performance is defined as resilient if their performance is equal or higher than the OECD median in all three PISA domains reading, mathematics and science. Both higher average performance and higher equity raise the number of resilient students (Agasisti et al., 2018 [34]). Fostering cultural activities, through extracurricular education is one successful strategy (Borgonovi and Pál, 2016 $6_{[35]}$ ), as in the programme "Kultur macht stark" (Prognos AG, 2016 $6_{[36]}$ ), see also Box 4. Nonetheless, the strength of the impact of socio-economic background on student performance in science remains above the OECD average (OECD, 2017 [37] $)$. The probability of weak performance is still 3 times higher among pupils with disadvantaged socio-economic background, for example in science (Figure 17). Performance differences 
are particularly strong between schools which differ in the socio-economic background of their pupils.

Figure 16. The share of resilient students has increased strongly over the past 9 years

Percentage of resilient students among disadvantaged students ${ }^{1}$, PISA 2006 and 2015

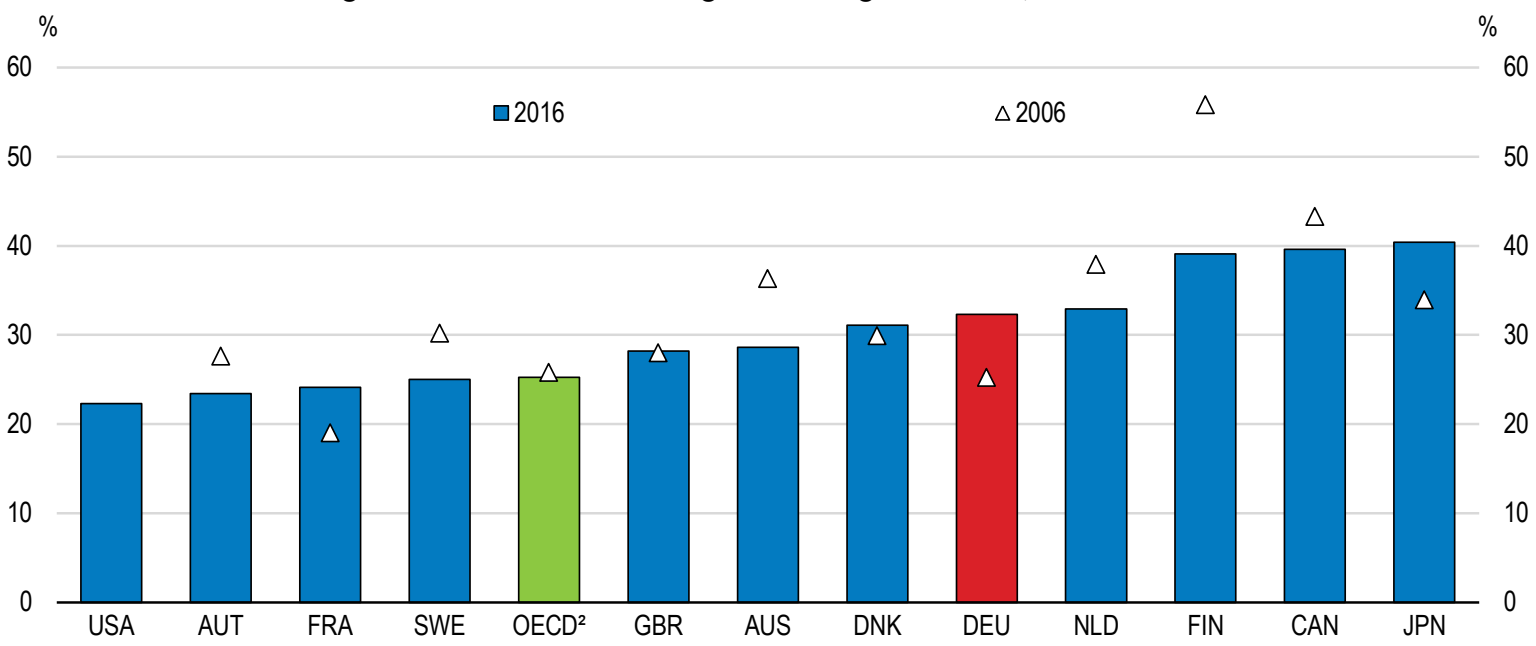

1. Resilient students are the $25 \%$ most disadvantaged students in their country according to the PISA index of economic, social and cultural status but are able to achieve at or above level 3 in all three PISA domains reading, mathematics and science. Level 3 corresponds to the median proficiency level across all OECD countries on average.

2. Unweighted average of available countries. PISA 2006 results in reading are not available for the United States.

Source: Agasisti, T., et al. (2018), "Academic resilience: What schools and countries do to help disadvantaged students succeed in PISA", OECD Education Working Papers, No. 167.

StatLink त्माज् http://dx.doi.org/10.1787/888933737799

High performance and greater fairness in education opportunities and outcomes are not mutually exclusive. Among the most successful countries and economies in mean PISA proficiency, socio-economic disadvantage tends to play a relatively minor role in explaining variation in student performance. One key factor that improves performance of pupils with disadvantaged socio-economic background is the integration of pupils with different socio-economic background in the same school (Agasisti et al., 2018[34]).

A majority of pupils, typically between 10 and 12 years of age, undergo a selection process into secondary schools where student performance or teacher recommendations from feeder schools are used as criteria. One of the principle objections to early tracking is that it reinforces intergenerational immobility in terms of educational achievement and later economic outcomes, although the impacts of tracking on student performance are controversial. Research shows considerable influence of gender, cultural and family background on the assigned type of track, reducing social integration. A relatively high rate of grade repetition also contributes (OECD, 2014 $[38]$ ).

The influence of parental background on offspring performance at secondary school tends to be lower in countries where tracking takes place at a later stage or in comprehensive systems with less ability grouping within schools. Early tracking appears to exacerbate achievement differences associated with the school's socio-economic mix without increasing overall performance (Causa and Johansson, 2010 [39]). Research by (Pekkarinena, $2009_{[40]}$ ), which exploits the fact that the move from tracking to a comprehensive system 
in Finland was implemented gradually across the country's municipalities during a six-year period, indicates that the reform reduced the impact of parental earnings on their childrens' earnings (so called intergenerational income elasticity) substantially, as pointed out in the OECD Economic Survey of Switzerland (OECD, 2017 [41]).

Figure 17. Disadvantaged students are at higher risk of low performance ${ }^{1}$

Likelihood of low performance among disadvantaged students, relative to non-disadvantaged students, 2015

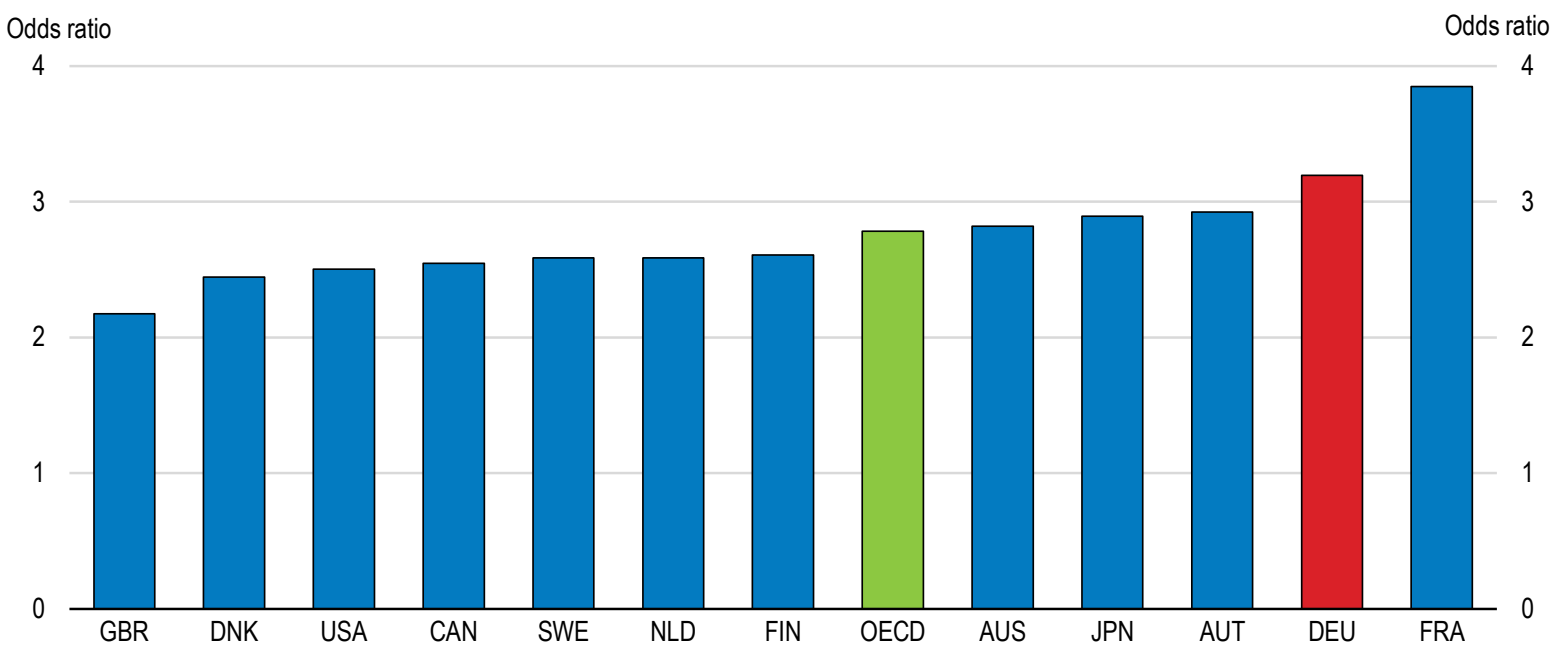

Note: A socio-economically disadvantaged student is a student in the bottom quarter of the distribution of the PISA index of economic, social and cultural status (ESCS) within his or her each country/economy.

1. Score below level 2 (baseline level of proficiency) in science in PISA.

Source: OECD (2016), PISA 2015 Results (Volume I): Excellence and Equity in Education.

StatLink 제패 http://dx.doi.org/10.1787/888933738464

Some Länder have taken important measures to avoid potentially negative effects of tracking on equity. The number of school tracks has fallen. In some Länder, in addition to the Gymnasium which prepares for university entry, there is only one school form, with several levels of courses. In Hessen parents can choose between 4-year and 6-year primary schools, and in Berlin and Brandenburg, all primary schools are comprehensive until grade 6 (age 12).

Tracking is only one of many factors which may contribute to unequal cognitive skill development. The incidence of poor learning outcomes is already substantial among 11-year-old children, who have been subject to tracking for at most a year (Mullis et al., $2017_{[42]}$ ). Among 11-year-olds, almost $20 \%$ of pupils reach at most basic reading competencies. The difference in results between pupils of parents that possess many books and those who have few books is marked, equivalent to what pupils in primary education learn in one year.

\section{Further improving early childhood education and care and full-day primary education}

Investing at an early stage in children's development and education can produce high returns on investments since this lays down a crucial foundation for future learning, especially for children with weak socio-economic background. A growing body of research recognises that high-quality early childhood education and care (ECEC) brings a wide 
range of benefits, for example, better child well-being and learning outcomes as a foundation for lifelong learning; more equitable child outcomes and reduction of poverty; increased intergenerational social mobility; more female labour market participation; increased fertility rates; and better social and economic development for the society at large (OECD, 2012 ${ }_{[43]}$ ). Analysis of data from the OECD Programme for International Student Assessment (PISA) finds that a student who did not attend early childhood education is about 3.1 times more likely than a student who attended for one year or more to perform below the baseline level of proficiency in science, after accounting for socio-economic status (OECD, 2017 [44]).

The number of enrolled children under the age of three has risen from $18 \%$ in 2008 to $33 \%$ in 2017. Enrolment of above-3-year-olds in early childhood education is near universal. The federal government continues to support the expansion of childcare facilities by means of targeted investment programs. For example, the "KitaPlus" programme, launched in 2016, focuses on the provision of a wider range of opening hours. However, demand is still higher than the number of available childcare places (Alt et al., 2017 ${ }_{[45]}$ ). It is welcome that the coalition agreement foresees providing more funding for early childhood education and care. It foresees reducing fees paid by parents and improving quality. It also foresees introducing a legal entitlement to full-day primary education.

Children with a migration background as well as children of parents with low levels of education attend early childhood education and care (ECEC) less and later, even though ECEC would have the biggest benefits for them (Schober, Spieß and Stahl, 2017 [46] $)$. In 2016, 20\% of under-3-year olds with a migration background attended an ECEC facility, while the share among under-3-year-olds without a migration background stood at 38\%. The participation of under-3-year-olds in childcare who have parents with low levels of education even decreased from $19 \%$ in 2012 to $16 \%$ in 2015 (Autorengruppe Bildungsberichterstattung, 2016 $[47]$ ).

Private funding still contributes $22 \%$ towards the cost of childcare, more than in most OECD countries $\left(\mathrm{OECD}, 2017_{[48]}\right)$. In relative terms, the financial burden on low-income households who make use of childcare facilities is still high high (Schmitz, Spieß and Stahl, $2017_{[49]}$ ). Surveys indicate that high-income households would be willing to pay more for childcare services than they do.

The effect of ECEC attendance on subsequent education outcomes depends on the quality of the interactions and learning environment in these institutions (Anders et al., 2011 $1_{[50]}$ ). Higher childcare quality also increases health benefits. Participation in formal childcare can substantially reduce health risks for children at higher age (Peter, 2014[51]). By encouraging more parents to make use of childcare facilities, it also boosts female labour market participation (Schober and Spieß, 2014 $4_{[52]}$ ). The quality of childcare is uneven in Germany (Stahl, Schober and Spiess, 2017 ${ }_{[53]}$ ). For example, there are differences in the staff-to-children ratio and in qualification levels (Bertelsmann Stiftung, 2017 [54]). Many young children from disadvantaged socio-economic backgrounds are enrolled in lowerquality institutions (Schober and Pia, 2017 $7_{[55]}$ ).

The federal and Länder governments have taken further initiatives to improve access to and quality of early childhood education and childcare, such as the programme "KitaEinstieg - Brücken bauen in Frühe Bildung" (Entry into ECEC - building bridges to early education), the programme "KitaPlus" or "Sprach-Kitas" (child care centers with focus on language education and development). In recent years, the German government has also supported improving the qualifications of daycare staff. The federal government and the 
governments of the Länder have also taken stock of progress in improving quality and identified further steps to be taken (Bundesministerium für Familie, Senioren, Frauen und Jugend, 2016 $[56])$.

It is particularly important to improve quality standards across Germany to help avoid quality gaps for young children who need the most support. However, this requires adequate monitoring of quality. The German government has therefore decided to participate in the OECD Starting Strong Teaching and Learning International Survey, which collects data on ECEC quality from ECEC staff and centre leaders. However, monitoring of quality may be insufficient in most individual Länder (OECD, 2016 ${ }_{[57]}$ ). In addition, incentives need to be developed to encourage parents with low socio-economic background to enrol their children, for example, with conditional cash benefits, in addition to free enrolment.

In Germany, $66 \%$ of primary schools provide full-day schooling and $40 \%$ of the pupils attend. Indeed, teaching time is short in international comparison (Figure 18). Differences between the Länder are marked. The quality of programmes is key for obtaining benefits from full-day schools. Many full-day schools provide mostly childcare in the afternoon, rather than education. Among schools which provide education also in the afternoon, afternoon teaching is often not integrated with the morning curriculum, reducing the benefits of full-day education (StEG, 2016 [58]); see also Box 4.

Figure 18. Instruction time in primary education is low

2016

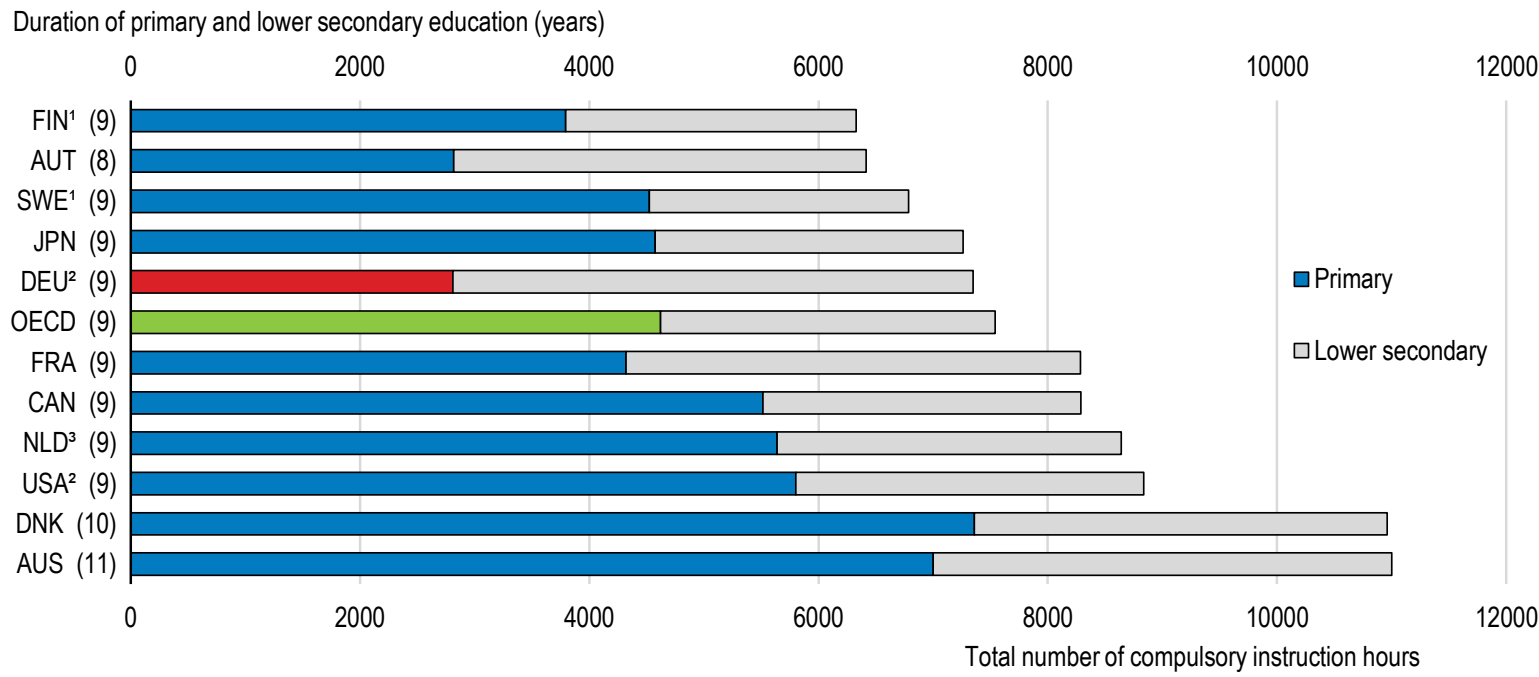

1. Estimated number of hours by level of education based on the average number of hours per year, as the allocation of instruction time across multiple grades is flexible.

2. 2015 for Germany and 2012 for the United States.

3. The number of grades in lower secondary education is three or four, depending on the track. The fourth year of pre-vocational secondary education (VMBO) was excluded from the calculation.

Source: OECD (2016), Education at a Glance 2016: OECD Indicators.

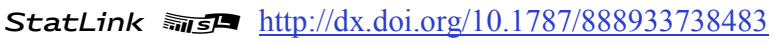




\section{Box 4. Realising the potential of full-day school to boost cognitive and non- cognitive skills: Results of evaluation in Germany}

Research commissioned by the federal government shows that all-day schools have the potential to have a positive influence on the individual development of pupils (StEG, 2016 $\left.{ }_{[58]}\right)$. High quality all-day school can strengthen social and emotional skills and thereby contribute to better success at school.

All-day schools foster non-cognitive personal and social skills, in particular motivation to learn and self-confidence. Indeed, these non-cognitive skills are key for success in the adult social and economic life. They also help acquire cognitive skills. Sports and music classes at all-day schools reach target groups of pupils with weak socio-economic background who did not previously make use of such opportunities (sports clubs, music or art schools).

All-day schools also support the reconciliation of work and family life, particularly as far as working mothers are concerned. Working parents and single parents are particularly likely to send their children to all-day schools. Families with fewer resources in particular consider that all-day schools relieve the pressure and have a positive effect on family life.

Full-day schooling aims at enhancing the individual promotion, in particular of pupils/students with migrant backgrounds or from difficult social backgrounds. Head teacher surveys also suggest that full-day schools make it easier to integrate children with special needs.

Enriching the social environment bears the potential to close the observed developmental gap in social skills between children with different socioeconomic status. Research suggests that children participation in programmes addressing prosocial behaviour can improve these skills especially among children with low socio-economic status (Kosse et al., 2016 $6_{[5]}$ ).

The biggest and most prominent programme at the federal level to strengthen such skills is "Kultur macht stark - Bündnisse für Bildung". The government spent EUR 50 million annually between 2013 and 2017 and the programme will be extended for additional five years. More than 450000 children and young people benefited from the programme. The target group of the programme is 3 to 18-years old children and young people from disadvantaged socioeconomic backgrounds. The programme supports local alliances of institutions offering cultural activities, including activities that relate to architecture, literature, music, theatre and circus as well as everyday culture with schools. Targets of the programme include educational equality, social participation and personality development of young people.

\section{Strengthening digital skills at school}

According to the International Computer and Information Literacy Study (ICILS) from $2013,30 \%$ of German pupils only had rudimentary computer skills. The use of digital media at school has barely expanded in recent years. According to the study, poor technical equipment contributes to low computer skills. More training of teachers in the teaching of ICT skills and in the use of ICT in general education could help improve student skills 
(Sachverständigenrat, 2017 $[8]$; Bos, 2014 $4_{[59]}$ ). Schools do not generally offer optional courses providing digital skills (Sachverständigenrat, 2017 $[8]$ ). However, new ICT technologies also offer opportunities to improve access to better education outcomes and better access to economic opportunities for pupils with low socio-economic background, for example, because they make it easier to provide tailored, individual support to each pupil (Eickelmann, Bos and Gerick, 2015[60]).

\section{Adapting the successful vocational education system in the light of skill-biased technological change}

An important strength of the dual system is cooperation between companies and public vocational schools. On-the-job training is complemented by teaching in part-time VET schools where students usually spend 12 hours per week. At VET school, one third of teaching is in general education and two thirds occupationally-specific education. The system is regulated by the federal government, the Länder, the business chambers and the social partners (Box 5).

Thanks to the dual system, Germany enjoys excellent integration of young people in the labour market and low field-of study mismatch, as argued above. It has contributed to maintaining manufacturing employment in Germany. This could also help explain why Germany has not experienced an increase in inequality on the same scale as the United States (Aizenman et al., 2017 $[61]$ ).

Vocational education programmes are adjusted regularly and quickly to adjust to technological change. Since 2000 two thirds of the 327 programmes have been revised at least once and 40 new ones have been created (Sachverständigenrat, $2017_{[8]}$ ). To address the changing skill requirements from digitalisation the Federal Ministry of Education has in introduced the programme "Berufsbildung 4.0" (VET 4.0). It includes the creation of inter-company vocational training centres and subsidies for the procurement of digital equipment by schools, to ensure VET graduates are equipped with up-to-date digital skills. The coalition agreement contains various plans to further promote digital skills in vocational education and training, such as comprehensive measures to digitally train teachers in vocational schools and further educating instructors, a digital equipment campaign for vocational schools and vocational training centres, as well as expanding VET 4.0.

Wage and employment prospects of vocational education graduates at higher age may be more exposed to risks as a result of technological change that occurs after they complete their degree. As the theory of endogenous technological change implies, firms become more likely to adopt modern technologies if workers whose skills complement new technologies are available. As a result, the supply of modern-skilled graduates may create its own demand at the expense of the demand for incumbent workers with outdated skills (Janssen et al., 2017 $[62]$ ). Moreover, as the demand for skills has become increasingly stronger for high and low-skill activities (as argued in Chapter 1 of the 2018 Economic Survey of Germany), the wage and employment of middle-skill vocational workers may continue to weaken. 


\section{Box 5. Institutional responsibilities in Germany's vocational education and training system}

The Federal Ministry of Education and Research has overall responsibility for VET strategy. The Länder have responsibility for the VET schools. They design the school curricula, train and pay the teachers and are responsible for legal supervision of the Chambers of industry and commerce, crafts and trades. Occupation-specific content is set according to a framework curriculum issued for each profession by the Standing Conference of Ministers for Education and Cultural Affairs of the Länder jointly for vocational subjects and by the Länder individually for general subjects (Hoeckel and Schwartz, 2010 $[63]$ ).

The social partners are involved in the development and updating of the curricula, issued by the Ministry of Economic Affairs and Energy in most cases, and determine apprenticeship salaries through collective wage negotiations.

The business chambers register apprenticeship contracts, assess the suitability of training firms and monitor their training, assess the aptitude of VET trainers, provide advice to training firms and apprentices, organise and carry out the final exams and issue the degree certificates.

The responsibility for funding vocational schools lies with the Länder (mainly teacher salaries) and local authorities (equipment, infrastructure), while companies bear the costs of training in the workplace. In some sectors, companies have created a general fund to which all companies pay contributions and through which the costs for the apprenticing institution are covered, while in other sectors each company bears its own costs. Overall, the biggest share of the costs for dual system VET falls to training firms (Hoeckel and Schwartz, $\left.2010_{[63]}\right)$.

While occupation-specific upper secondary vocational education and training helps with school-to-work transitions, especially in countries with strong apprenticeship systems, it appears to be linked with a stronger decline in employment prospects later in life, relative to general education or tertiary education Table 2.1. This is also shown by evidence across high-income countries (Hanushek et al., 2015 $[3]$; Hampf and Woessmann, 2016 ${ }_{[64]}$; Forster et al., 2016 $6_{[65]}$ ). According to the most recent evidence (Hampf and Woessmann, 2016 $6_{[64]}$ ), who refute contrary results by others on this point (Forster et al., 2016 $6_{[65]}$ ), the decline in employment prospects at higher age is strongest in apprenticeship-based training systems.

The risk of long-term unemployment appears to rise relatively strongly for graduates from vocational upper secondary education above the age of 45 years, as research undertaken for the OECD with German Socio-Economic Panel (SOEP) data shows. Among 45-55year-old graduates, a quarter of unemployment spells observed since 2005 has ended with a new job only after 22 months. The research also shows that longer unemployment spells generally result in a bigger loss of subsequent wage earnings, compared to what they would have been without the unemployment experience. There appears to be a significant depressing impact of unemployment duration on subsequent wages in particular for unqualified workers and workers with intermediate vocational skills, whereas this relationship is not statistically significant for other skill groups. However, differences between skill groups are not statistically significant either. Across all skill groups, unemployment depresses subsequent wages more strongly at higher age. Unemployment 
appears to depress wages in subsequent employment somewhat less for workers with a university degree than for vocationally-trained workers (Effenberger et al., 2018[66]). All this evidence points to the importance of preparing workers for the labour market impacts of technological change, especially at higher age.

Table 1. Employment rates by educational attainment and age group, 2016

\begin{tabular}{|c|c|c|c|c|c|}
\hline Age group & & $\begin{array}{l}\text { Below upper } \\
\text { secondary education }\end{array}$ & $\begin{array}{l}\text { Upper secondary and } \\
\text { post-secondary non- } \\
\text { tertiary general } \\
\text { education }\end{array}$ & $\begin{array}{l}\text { Upper secondary and } \\
\text { post-secondary non- } \\
\text { tertiary vocational } \\
\text { education }\end{array}$ & Tertiary education \\
\hline & $25-34$ & 55.3 & 55.0 & 86.3 & 87.0 \\
\hline & $35-44$ & 63.2 & 71.9 & 88.0 & 91.4 \\
\hline & $45-54$ & 67.1 & 77.1 & 87.3 & 93.5 \\
\hline & $55-64$ & 51.5 & 65.5 & 67.5 & 80.3 \\
\hline
\end{tabular}

Source: OECD (2018), "Education at a glance: Educational attainment and labour-force status", OECD Education Statistics (database).

OECD research with data from the SOEP, which collects data on individuals throughout their lifetime, indicates that similar findings apply to earnings. Whereas average earnings of graduates from academic upper secondary and tertiary degrees more than double, average earnings of upper secondary vocational graduates grow by only $30 \%$ between the age of around 25 and 50 years. Average earnings of workers with tertiary vocational skills also rise relatively slowly with experience (Figure 19). The dispersion of earnings among individuals within the same education group is however large, especially for vocational education graduates. In fact, $28 \%$ earn more than the average university graduate.

When vocational training programmes are updated to integrate new technologies, the earnings of incumbent workers, who completed their training before the update, fall. This is shown by evidence on earnings of machinery technicians who had completed their apprenticeship after the training programme was updated to include up-to-date information and communication technology (Janssen et al., 2017 $7_{[62]}$ ). Even young incumbent workers experienced long-lasting earnings losses after the IT-skilled graduates entered the labour market. The estimated loss was only around 5\%. However, if several updates occur over a lifetime the losses could be a multiple. New IT-skilled graduates crowded out incumbent workers of their occupation, and incumbent workers forwent promotion, although incumbents experienced only little unemployment (Janssen et al., 2017[62]). Incumbent machining metal operators became significantly less likely to remain in the metal working sector and significantly more likely to enter the service sector, particularly, low-wage service jobs. The risk of adverse consequences of routine-biased technological change appears to be most substantial for medium-educated workers, in particular, for mediumeducated production workers (Goos, Salomons and Manning, 2014 $4_{[67]}$ ).

Entry in vocational education has diminished the most in those sectors which have experienced the most rapid renewal of vocational education programmes, namely in industry and the crafts (Sachverständigenrat, $2017_{[8]}$ ), which suggests that uncertainty and expectations about depreciation of technology-specific skills may have made youth more attracted to university study programmes. 
Figure 19. Earning profiles by education level

Yearly earnings in euros, by educational level, 25-65 year-olds, men

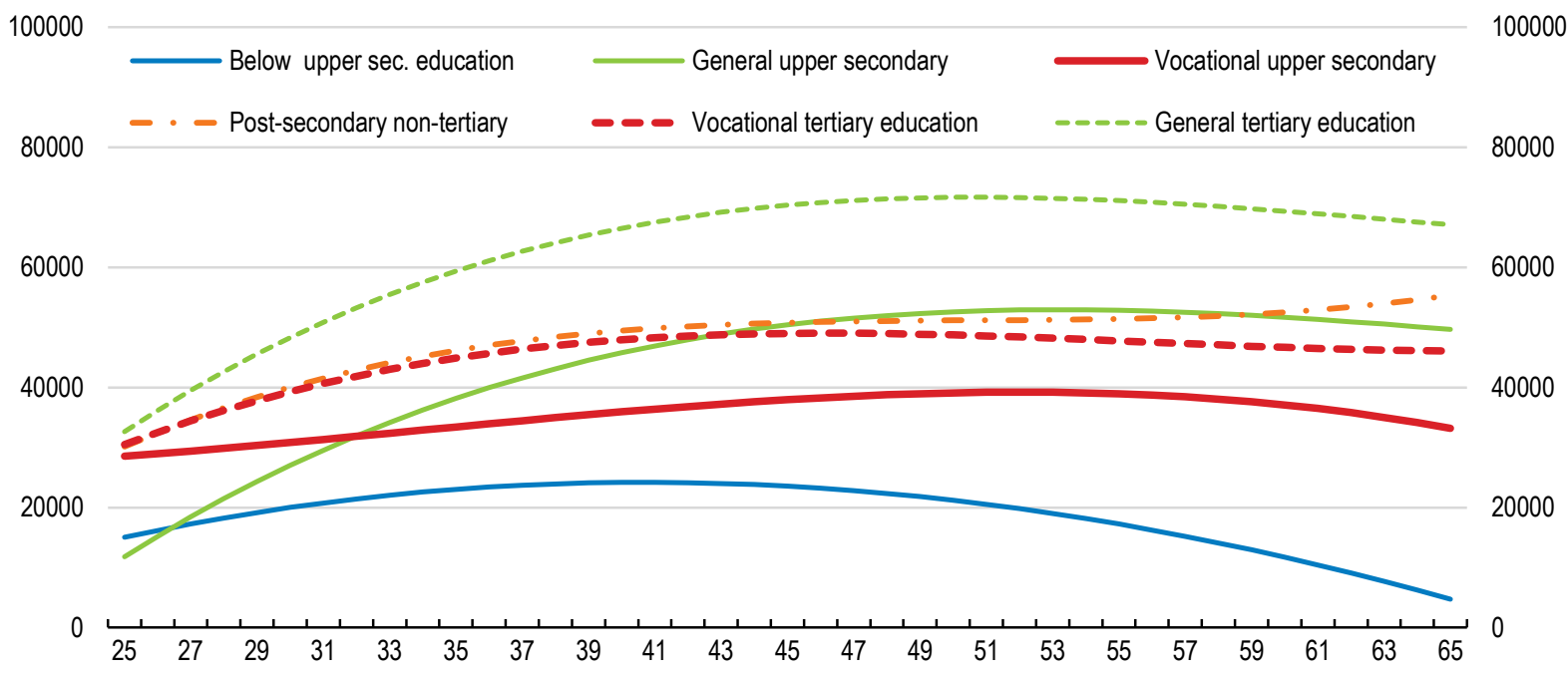

Note: The earning profiles are estimated on the basis of data from the German Socio Economic Panel, which follows individuals living in Germany throughout their lifetime. The sample includes data from 1984 to 2012 for individuals living in Western Germany. Earning profiles were estimated by running a regression of earnings of each economically active individual on time dummies as well as linear and non-linear age variables for each education level. They capture average profiles. There is heterogeneity of earnings around each estimated profile. Individuals with post-secondary non-tertiary attainment typically hold both a general upper secondary and a vocational upper secondary degree.

Source: OECD calculations on the basis of the German Socio Economic Panel (SOEP).

StatLink त्माज् http://dx.doi.org/10.1787/888933738502

\section{Stronger basic cognitive skills are needed}

Literacy skills are relatively low among young people in vocational education coming from lower secondary education compared to countries who are strong PIAAC performers (Japan, Finland, Australia), for example with respect to reading (Figure 20). As the PIAAC Survey of adult skills was undertaken in 2012, it is likely that test scores would today be higher, reflecting reforms which have boosted PISA scores for 15 year-olds, especially among those with weak socio-economic background. Many of these youth have entered upper secondary vocational education subsequently. However, PIAAC scores among upper secondary vocational students and graduates also appear little higher than those of young people with no upper secondary degree, suggesting that cognitive skills improve little in vocational education schools. By contrast, academic secondary as well as tertiary university students and graduates have strong cognitive skills. Tertiary vocational graduates do less well.

Also, only a minority of upper secondary vocational education pupils learn English, fewer than in most other vocational education systems across Europe (Figure 21). Stronger English language skills are in higher demand in workplaces which are more digitalised and would also prepare graduates better for globalisation (CEDEFOP, 2017 ${ }_{[17]}$ ). In 2015, the Länder adopted a framework agreement to be able to better react to the requirements of a globalised working world in vocational education. The opportunities to spend time abroad during education and training were improved. This includes the extension and deepening of foreign language competence according to its significance in each vocational qualification. 
Figure 20. Literacy skills improve modestly in upper secondary vocational education

Mean literacy proficiency and distribution of literacy scores, by educational attainment, 16-29 year-olds, 2012

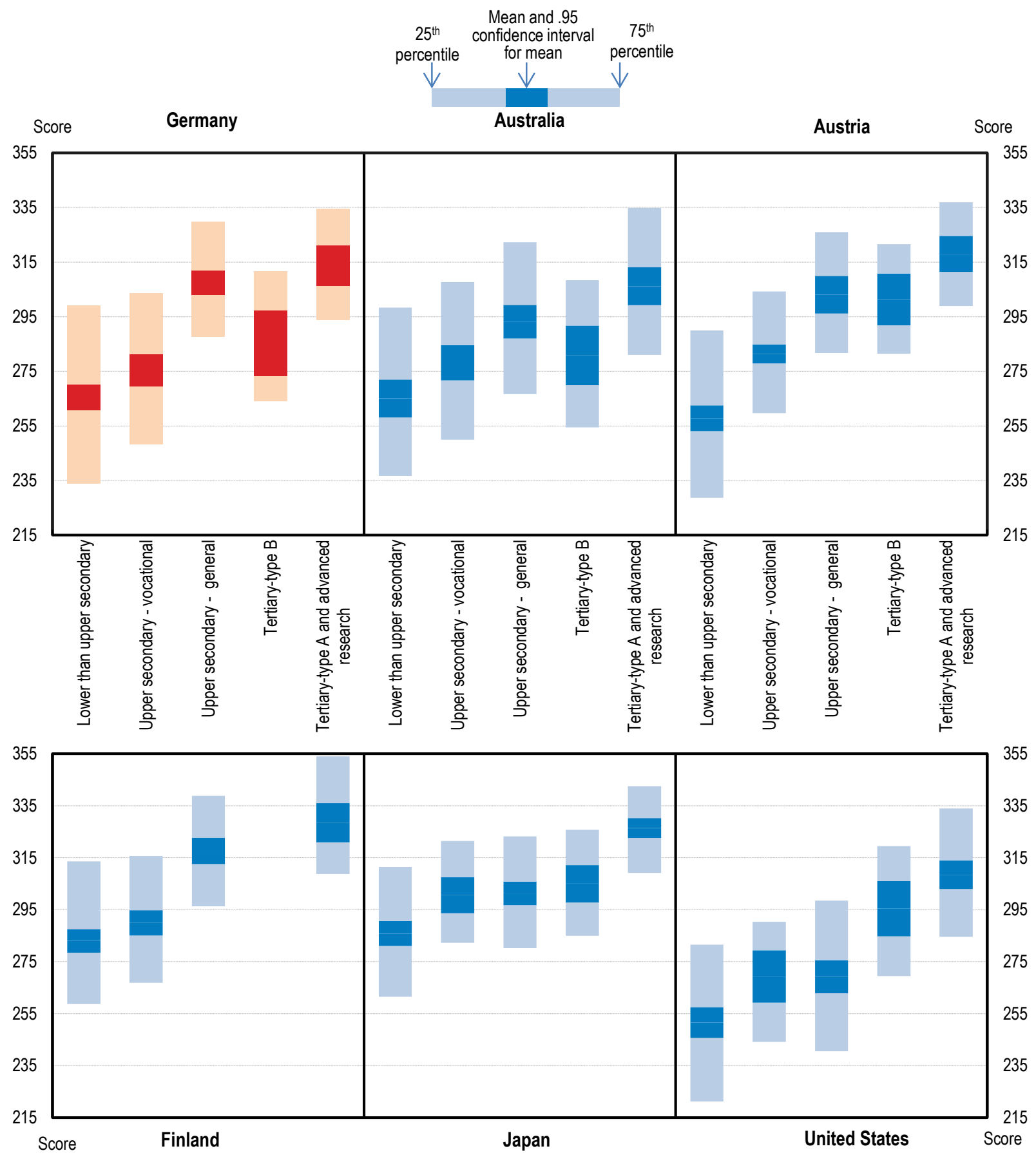

1. The estimate for Tertiary-type B for Finland is based on a sample size very close to 30 and is not shown at the country's request.

2. Only a sample of countries is shown as an example.

Source: OECD (2013), OECD Skills Outlook 2013: First Results from the Survey of Adult Skills.

StatLink 제패 http://dx.doi.org/10.1787/888933737818 


\section{Figure 21. Few students in vocational education learn English}

Share of students learning English in upper secondary vocational education, 2016 or latest year

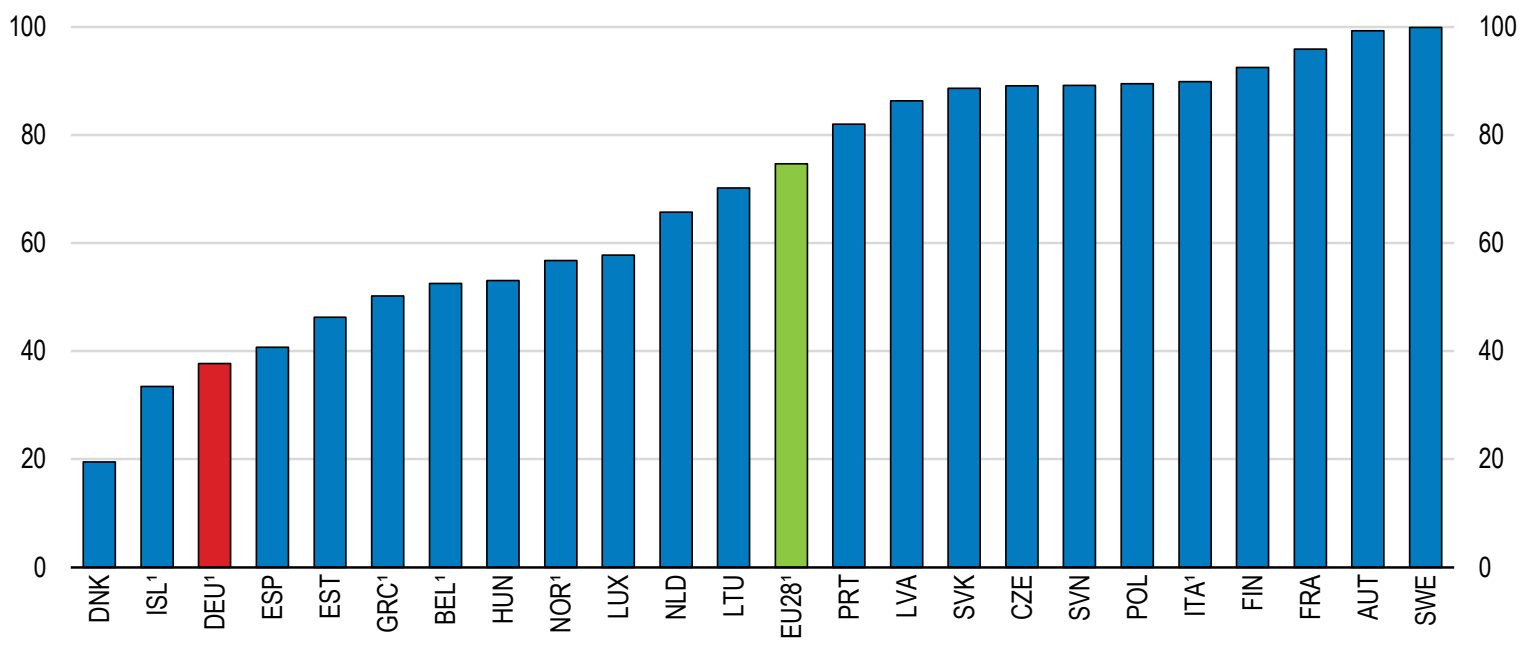

1. 2015 for Belgium, Germany, Greece, Iceland, Italy, Norway and the European Union. Source: Eurostat (2018), Education and training Statistics (database).

StatLink 제패 http://dx.doi.org/10.1787/888933738521

Graduates with low cognitive skills levels may be less prepared to acquire new skills and adapt to evolving technologies and skills demand. For example, adults with lower cognitive skills are less likely to engage in job-related adult education and training later on. Modest cognitive skills also weaken access of upper secondary vocational education graduates to higher education, which is low (see below). Cognitive skills, and their impact on the capacity to engage in lifelong learning, may be especially important in view of the evidence of rising demand for high-skill workers in the context of digitalisation. Ensuring that VET graduates have strong literacy and numeracy skills is therefore essential. One policy option may therefore be to strengthen general cognitive skills within the apprenticeship system (Hoeckel and Schwartz, 2010[63]). Strengthening non-cognitive general skills such as to perform managing, communicating and marketing tasks, as well as ICT skills, is also important. A strong ability to perform such non-routine tasks can also protect workers against the job risks of automation.

The evaluation of dual system students at the end of the apprenticeship is dominated by the final chamber exam, which tests occupation-specific skills. It alone determines whether the apprentices receive their formal VET qualification. The training employer also provides a written evaluation and the part-time VET school provides a certificate from the part-time VET school. But general education examination results (maths, German, etc.) are not generally included in the degree diploma. Inclusion of the school mark as a component of the final diploma is voluntary. Because their school performance does not count in the chamber exam, students may not take their schooling seriously (Hoeckel and Schwartz, $\left.2010_{[63]}\right)$. While around $75 \%$ of trainees themselves report satisfaction with the firm-based training only 55\% do so for the schooling part (Institut der deutschen Wirtschaft, 2015 [68]).

One way of improving general skills would be to introduce a first year to develop basic skills, as recommended by the OECD (Hoeckel and Schwartz, 2010 $0_{[63]}$ ), offering general education as well education in a broad professional area. This would also postpone occupational choice, helping to reduce traditional gender bias. Some OECD countries, for 
example Denmark, already organise their VET system this way and offer a general first year to students where they can try out different elements of a professional cluster before committing themselves to a specific occupation.

\section{Access to higher education has improved, but more could be done}

The Länder opened formal access to universities for vocational education graduates in 1995. Graduates from apprenticeships can access university with further qualifications, such as vocational education degrees at the tertiary level. In addition, vocational education graduates are also given access to university education in their area of expertise after three years of professional experience and an entrance exam or a trial study period. Recently programmes combining apprenticeships with higher education have been created (duales Studium - dual studies), but they aim at youth who have done general upper secondary education and so have access to university anyway. Only $2.4 \%$ of young people entering university got there on the basis of a vocational upper secondary degree.

One Land decided to go further and to give access to university without the three-year professional experience requirement, while maintaining the entrance exam or trial study requirement. Indeed, evaluation has shown that professional experience did not play an important role for the chances of success at university (Euler and Severing, 2016 $6_{[69]}$ ). Moreover, if students can pursue higher education earlier, they can earn a return on it over a longer period of time, improving incentives to do so.

Graduates from apprenticeship programmes interested in taking study further may need special support in order to start studying. Higher education institutions have adapted the structure and organisation of courses of studies regarding the needs of this target group. In addition, the higher education institutions offer preparatory courses, and distance-learning and part-time programmes, so that a course of study can be completed while working. Nonetheless, this share has barely risen since 2011. Easier access to higher education would also improve social integration among higher education students and foster upward intergenerational social mobility.

There is also scope to develop general guidelines to improve the recognition of skills acquired in vocational education by universities, so vocational education graduates can acquire higher education qualifications more easily. The federal and regional governments could also provide financial incentives to universities to provide study offers that facilitate the transition to vocational education graduates (Wissenschaftsrat, 2014 $[70]$ ).

\section{Boosting life-long learning would raise well-being and inclusiveness}

Life-long learning is becoming more and more important as rapid technological change makes skills obsolete more quickly. At the same time the working lives are likely to lengthen as life expectancy rises, while fewer young workers join the labour market after completing full-time education. Most workers expected to be active in the labour market in 2030 are already working today, yet technologies will have changed skills demand substantially, in part through automation (Chapter 1 of the 2018 Economic Survey of Germany). Work-related lifelong learning can take many forms, including formal and nonformal education, on-the-job training and informal education (OECD, 2017 $\left.7_{[12]}\right)$.

Life-long learning raises earnings and improves employability among participants (European Commission, Directorate General for Employment, Social Affairs and Inclusion, 2015 [71]). In Germany subsidised adult vocational training (mostly for unemployed workers) has been shown to increase the probability to be employed by about 
$10 \%$ to $20 \%$ (McCall, Smith and Wunsch, 2016 $6_{[72]}$ ). OECD research with data from the German Socioeconomic Panel indicates that participation in employer-sponsored training reduces unemployment among experienced workers.

Life-long learning also helps improve economic opportunities for workers with poor qualifications, boosting inclusiveness. Adult learning opportunities improve labour market integration of the 1.5 million refugees, most without formal certified skills, Germany received for humanitarian reasons in 2015 and 2016 (OECD, 2016 $\left.{ }_{[18]}\right)$. Life-long learning also improves job satisfaction, in part through career advancement (OECD, 2017 $[73]$; Roggenkamp, 2016 ${ }_{[74]}$ ). It increases self-confidence and overall life satisfaction (European Commission, Directorate General for Employment, Social Affairs and Inclusion, $2015_{[71]}$ ). Life-long learning can also boost civic engagement. It can also improve learning and wellbeing among children, as the impact of adult education on youth education outcomes is marked.

Adult participation in life-long learning has risen little in recent years and is well behind best-performing high income countries, such as Denmark, Finland and Sweden, according to Labour Force Survey data (Figure 22) and the Adult Education Survey (AES). The latest results of the Adult Education Survey show that one in two adult Germans participated in at least one adult education measure in 2016 while in the best-performing countries this number rises to nearly three out of four. Participation in formal and non-formal education and training is relatively low also according to the 2012 OECD PIAAC Survey. As in other countries, participation is particularly low among older workers as well as among people with only basic education or low literacy skills, but also among graduates of vocational education. Most non-participants do not want to participate and see no need for education and training, more so than in peer countries. This is consistent with the low readiness to learn according to the PIAAC study and may reflect discouraging experience made in fulltime initial education at young age, especially among the unskilled. The new government's coalition agreement proposes to develop a national strategy for continuing education, to be agreed with social partners, with the aim of coordinating existing programs and strengthening life-long learning. This is welcome. However, care must also be taken that the plan takes the interests of unskilled workers into account, who are often weakly attached to the labour market. Their interests may be less well represented by the social partners.

Among German medium-sized enterprises fewer than 50\% provide ICT training. In other high-income countries this share can reach $55 \%$ to $60 \%$. Training by companies is mostly directed to medium and high-skilled workers, not low skilled workers (OECD, 2017 $\left.{ }_{[75]}\right)$.

Germany is among the few countries with lower female participation compared to men. Women above the age of 35 are particularly unlikely to participate in life-long learning, likely reflecting family responsibilities. Women with young children in the household participate less than women with older children (PIAAC) (OECD, 2017 ${ }_{[12]}$ ). Far more women than men report that family responsibilities and distant training venues are barriers (EU Adult Education Survey 2016). Men's participation rates are also substantially lower above the age of 35. Conceivably, family duties can lower participation by both parents, especially in the context of couples with one main earner. It may be easier to participate in adult education in couples in which both partners can work if participation results in some loss of wage income. Indeed part-time employment boosts participation by men. The opposite is true for women. 
Figure 22. Participation in life-long learning can be raised further

Participation in life-long learning ${ }^{1}, \%$ of population aged 26-64, 2017

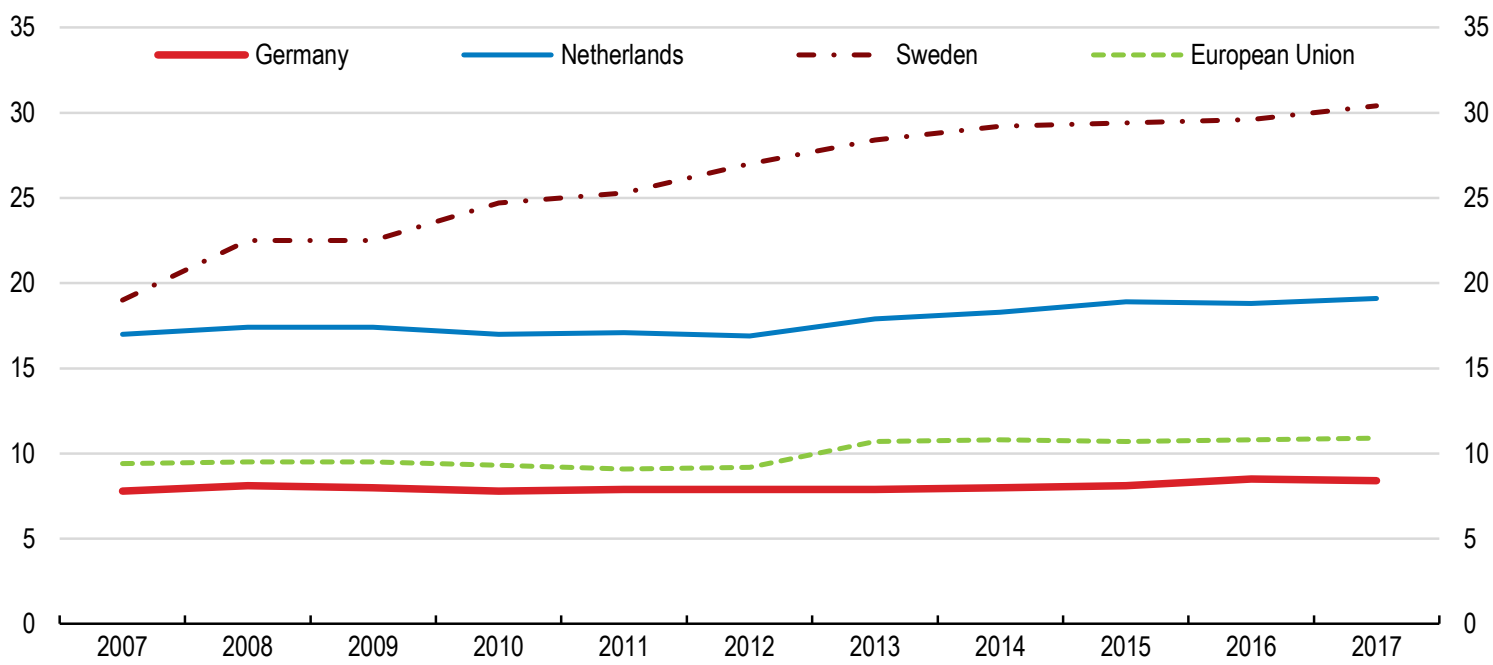

1. Includes formal as well as non-formal education and training. The reference period for the participation is the four weeks prior to the interview.

Source: Eurostat (2018), Education and training (database).

StatLink त्ञात् http://dx.doi.org/10.1787/888933737837

\section{Improved modular training offers could boost life-long learning}

Several OECD studies examine policy practices to encourage lifelong learning in order to respond to the changing skill needs $\left(\mathrm{OECD}, 2017_{[76]} ;{ }_{[77]} ;{ }_{[78]} ; 2014_{[79]} ; 2003_{[80]}\right)$. Steps to better validate uncertified skills acquired-on-the job, combined with developing modular learning approaches, can boost incentives to participate in life-long learning. In this way, adults could target formal learning efforts to those skills they still need to obtain a desired qualification. Such an approach, in the context of demographic change, may also allow employing education and training infrastructure better whilst its utilisation by young people in full-time education falls. To this end, Germany is well-placed to build on its excellent vocational education system including the involvement of the social partners and business chambers which already play a role in validating skills (Desjardins, $2017_{[81]}$ ). Since 2005, vocational education qualifications can be pursued part-time, so it could be more easily used in the context of adult learning, although this option is rarely taken up.

By making it easier to have skills certified, effective systems for identifying, recognising and validating skills, including those acquired on-the-job, pay a triple divided: 1) they improve opportunities to use skills more effectively reducing skill mismatch; 2) they boost activation and worker bargaining power, with a positive impact on wages; and 3) they create incentives for adults to engage in continuous skills development (OECD, 2017 $7_{[77]}$ ). When there is no validation of informal competences workers find themselves obliged to follow courses for skills they already possess (OECD, 2016 $\left.{ }_{[82]}\right)$. Skills recognition can hence avoid unnecessary repetition and lower training costs $\left(\right.$ OECD, 2003 $\left.{ }_{[80]}\right)$. This could boost motivation and the completion of learning programmes. The impact may be substantial as informal learning on-the-job is widespread (De Grip, 2015[83]). Governmentfunded recognition of skills acquired on-the-job has boosted adult learning in Portugal, especially among the unqualified. The modular training offers for the unemployed reduced the duration of unemployment (Lima, 2012 $\left.{ }_{[84]}\right)$. Also in Denmark a modular approach to 
adult learning boosted participation, including among unskilled adults (Desjardins, $\left.2017_{[81]}\right)$.

Counselling and assistance can help identify suitable further training to obtain a complete formal qualification. Counselling is offered in OECD countries with well-implemented skills validation and certification systems (Gaylor, Schöpf and Severing, 2015 $5_{[85]}$ ). The Federal Employment Agency already offers independent professional career guidance nationwide. It involves the provision of advice and information concerning career choice, occupations and the respective requirements, funding options for vocational education and training, developments in the working world, the situation and expected trends in the job market, and finding a job. Furthermore the Federal Ministry for Education and Research has created an advisory service which it is extending. The coalition agreement also proposes to improve information and counselling services.

The benefits may be particularly large for adults with no formal qualifications. Achieving a first qualification can open access to higher-level qualifications (Bertelsmann Stiftung, $\left.2018_{[86]}\right)$. Skill recognition may hence foster equity in educational outcomes including for older workers, low-skilled employees and migrants (Kis and Windisch, 2018 ${ }_{[87]}$ ). Modular training offers combined with formal skills recognition can also make it easier for workers to keep their skills up to date and adapt to technological change, helping to maintain employability at higher age. Skills recognition will also make it easier for workers to move to emerging occupations in fields related to their initial VET training, improving skills use (Kis and Windisch, 2018 ${ }_{[87]}$ ). Modular life-long learning offers need not imply lowering standards for the qualifications required for specific professions but widens access to such qualifications (Kis and Windisch, 2018 ${ }_{[87]}$ ).

In Germany, training modules have been defined in the vocational education system (e.g. Kölner Bildungsmodell, Perspektive Berufsabschluss, TrialNet), and in advanced further training programs (master degrees in the crafts). However, it is not possible to complete only selected modules and have them certified. Also in taking an examination for the purposes of skills recognition (Externenprüfung), missing skills in part of the examined competences leads to failing the whole examination. Skills proven in successful parts of the examination are not recognised (Wittig and Neumann, 2016 $6_{[88]}$ ). In the White Paper "Work 4.0" the government has recognised that modularisation needs to be strengthened to improve qualifications among the adult population. The coalition agreement plans to support further development of attractive, learning opportunities accessible to the lowskilled to allow for more inclusiveness.

Validation and assessment of skills obtained on-the-job have been initiated in Germany to facilitate the integration of immigrants, especially refugees (such as in the programmes include "Recognition Finder"). A pilot project has also been initiated to recognise skills of formally unqualified workers (Integration through Qualification Programme; ValiKom). These should be further developed to a general competence recognition system, recognising both (modular) formal and non-formal qualifications and enabling workers to receive certificates when they complete a full professional qualification, comparable to certificates of formal education (Bertelsmann Stiftung, 2018 ${ }_{[89]}$ ). Applying a unified competence approach could also allow for more transparency. There are many certified adult training programmes, sometimes certiying similar competencies. This reduces the information value of certificates (Wittig and Neumann, 2016 ${ }_{[88]}$ ).

Overall, compared to some other European OECD countries skill validation and recognition is weak in Germany (Bertelsmann Stiftung, 2018 ${ }_{[89]}$ ). In many countries there is a legal entitlement for access to skills validation, backed up with public funding (e.g. 
France, Norway, Denmark, Finland, Switzerland) (Gaylor, Schöpf and Severing, 2015 $5_{[85]}$ ). According to a survey by the Federal Institute of Vocational Education and Training (BIBB) these should also be adopted in Germany (Velten and Herdin, 2016[90]). Recognising work-based learning also demands the use of more task-based methods in skill validation processes (e.g. final "external" examination, Externenprüfung) rather than just offering formal exams (Gaylor, Schöpf and Severing, 2015 [85]).

\section{Strengthening support for life-long learning}

OECD work suggests that government financial support for life-long learning should be targeted to adults with the lowest qualification or literacy level (OECD, 2003 [80]). While the impact of government funding on participation in adult education is not clear overall, when it comes to the low-skilled public spending can make the largest difference (OECD, $2003_{[80]}$ ). Recent evidence confirms this (European Commission, Directorate General for Employment, Social Affairs and Inclusion, 2015 $5_{[71]}$ ). Indeed, low-income, low-education individuals have the lowest capacity to pay and may also be least aware of the benefits of education.

Firms invest less in low skilled employees because of lower returns (OECD, 2003 $\left.{ }_{[80]}\right)$. However, the social returns of life-long learning for adults with low qualifications are likely to be higher because it may help reduce unemployment benefit claims and other transfer spending for low income households, and boost inclusive growth. While subsidies to businesses also increase participation in life-long learning (European Commission, Directorate General for Employment, Social Affairs and Inclusion, 2015 [71]), businesses typically do not address the needs of low skilled employees, such as to boost general skills, including ICT, language or soft skills (OECD, 2017 ${ }_{[91]}$; McCall, Smith and Wunsch, $2016_{[72])}$.

Germany offers a multitude of financing schemes aimed at a variety of groups. Recently, government support for adult learning has been strengthened (e.g. with the amended Advancement Promotion Act). However, a review of the programmes show that there is little support for low-skilled adults who are neither unemployed nor at risk of job loss; see (Bundesministerium für Bildung und Forschung,(n.d.)[92]; Deutsches Institut für Internationale Pädagogische Forschung, 2018 ${ }_{[93]}$; Bundesagentur für Arbeit,(n.d.)[94]), for programme overviews). Germany could target funding to low-skilled low-income workers (OECD, 2017 [77])

Lost earnings are a key barrier to private investment in adult education and training (OECD, $\left.2017_{[95]}\right)$. Paid educational leave is available in most Länder but is limited to 10 days only within two years. An expansion of paid educational leave could boost participation. The coalition agreement proposes to expand financial support and to consider the implementation of individual training accounts.

Current financial support and educational leave generally require participants to complete a full programme leading to a new professional qualification. In order to allow for more flexibility, these policies could be adapted to support modular programmes. Modular training and its funding should be accompanied by close professional counselling. Indeed, empirical evidence suggests that guidance and counselling boost training participation, reinforcing the positive impact of financial support (European Commission, Directorate General for Employment, Social Affairs and Inclusion, 2015 $\left.5_{[71]}\right)$.

According to the European Inventory on the validation of non-formal and informal learning (CEDEFOP, 2017 ${ }_{[96]}$ ) low-skilled individuals, early school leavers, those without jobs and 
at risk of unemployed, older workers, immigrants and people with disabilities take up validation opportunities insufficiently. Since benefits are likely highest for these groups, public support should be focussed on them. 


\section{Recommendations for improving skills and their use}

\section{Reduce skill mismatch}

- Increase the minimum amount of time the second parent has to take parental leave, from the current two months, for the couple to receive the maximum leave entitlement.

- Improve housing supply in dynamic cities fostering densification in urban areas, for example with incentives for compact development on brownfield sites.

\section{Improve ICT skills}

- Expand ICT equipment at schools, improve teachers' digital teaching skills and the offer of digital courses at schools.

\section{Improve equity in education}

- Raise quality standards in childcare and early childhood education.

- Expand primary education to high-quality full-day education programmes.

- Use evaluation to guide full-day primary school programme design.

- Introduce more generous grant-only financial support for university students from low-income households and parents with low-education background.

- Require a regular qualitative evaluation of pedagogical quality in childcare in all Länder.

- Delay tracking in compulsory education.

\section{Improve upskilling opportunities in the vocational education system}

- Strengthen general education in vocational schools, and maintain the strong labour market orientation of vocational education and training.

- Introduce nationwide benchmarking of quality of learning outcomes in part-time dual vocational schools.

- Improve access to university education for upper secondary vocational graduates, for example by doing away with requirements of professional experience, and by strengthening incentives to universities to offer suitable programmes for vocational education graduates.

\section{Boost participation in life-long learning}

- Offer more training programmes for the modular acquisition of qualifications in life-long learning and foster the recognition of skills acquired on-the-job.

- Strengthen support for unskilled adults to obtain professional qualifications.

- Ensure modular training contributes towards full qualifications.

- Provide financial incentives for employers to provide workplace learning for the low-skilled. 


\section{References}

Agasisti, T. et al. (2018), "Academic resilience: What schools and countries do to help disadvantaged students succeed in PISA", OECD Education Working Papers, No. 167, OECD Publishing, Paris, http://dx.doi.org/10.1787/e22490ac-en.

Aizenman, J. et al. (2017), Vocational Education, Manufacturing, and Income Distribution: International Evidence and Case Studies, National Bureau of Economic Research, Cambridge, MA, http://dx.doi.org/10.3386/w23950.

Alt, C. et al. (2017), DJI-Kinderbetreuungsreport 2017; Inanspruchnahme und Bedarfe aus Elternperspektive im Bundesländervergleich, Deutsches Jugendinstitut, https://www.dji.de/fileadmin/user_upload/bibs2017/DJI_Kinderbetreuungsreport_2017.pdf (accessed on 16 May 2018).

Anders, Y. et al. (2011), "Home and preschool learning environments and their relations to the development of early numeracy skills", Early Childhood Research Quarterly, Vol. 27, pp. 231-244, http://dx.doi.org/10.1016/j.ecresq.2011.08.003.

Andrews, D., A. Caldera Sánchez and Å. Johansson (2011), Housing Markets and Structural Policies in OECD Countries, OECD Publishing, Paris,, http://dx.doi.org/10.1787/5kgk8t2k9vf3-en.

Autorengruppe Bildungsberichterstattung (2016), Bildung in Deutschland 2016. Ein indikatorengestützter Bericht mit einer Analyse zu Bildung und Migration., Bertelsmann Verlag, Bielefeld.

Bertelsmann Stiftung (2018), Formale Unterqualifikation auf dem deutschen Arbeitsmarkt.

Bertelsmann Stiftung (2018), Ungelernte Fachkräfte: Formale Unterqualifikation.

Bertelsmann Stiftung (2017), Länder-Monitor Frühkindliche Bildungssysteme.

Borgonovi, F. and J. Pál (2016), "A Framework for the Analysis of Student Well-Being in the PISA 2015 Study", OECD Education Working Papers 40, http://dx.doi.org/10.1787/5jlpszwghvvb-en.

Bos, W. (2014), ICILS 2013: Computer- und informationsbezogene Kompetenzen von Schülerinnen.

Bundesagentur für Arbeit((n.d.)), Fördermöglichkeiten in der beruflichen Weiterbildung, https://www.arbeitsagentur.de/karriere-und-weiterbildung/foerderung-beruflicheweiterbildung (accessed on 25 January 2018).

Bundesinstitut für Berufsbildung (2016), VET Data Report Germany 2015.

Bundesinstitut für Berusbildung (2017), Jahresbericht 2016.

Bundesinstitut für Bevölkerungsforschung (2017), Arbeitszeit neu gedacht!, Bundesinstitut für Bevölkerungsforschung.

Bundesministerium für Bildung und Forschung((n.d.)), Weiterbildung, https://www.bmbf.de/de/weiterbildung-71.html (accessed on 25 January 2018).

Bundesministerium für Familie, Senioren, Frauen und Jugend (2016), Frühe Bildung weiterentwickeln und finanziell sichern. 
Caliendo, M., S. Künn and R. Mahlstedt (2017), “The return to labor market mobility: An evaluation of relocation assistance for the unemployed", Journal of Public Economics, Vol. 148, pp. 136-151, http://dx.doi.org/10.1016/J.JPUBECO.2017.02.008.

Causa, O. and Å. Johansson (2010), "Intergenerational Social Mobility in OECD Countries", OECD Journal: Economic Studies, , Vol. Volume 2010, http://dx.doi.org/10.1787/eco studies-2010-5km33scz5rij.

CEDEFOP (2017), European Inventory on Validation of Non-Formal and Informal Learning, European Union.

CEDEFOP (2017), European Skills and Jobs Survey.

Chapman, B. (2006), Income Contingent Loans for Higher Education: International Reforms, Elsevier, North Holland.

De Grip, A. (2015), The Importance of Informal Learning at Work, http://dx.doi.org/doi: 10.15185/izawol.162.

Desjardins, R. (2017), Political Economy of Adult Learning Systems: Comparative Study of Strategies, Policies and Constraints, Bloomsbury Academic.

Deutsches Institut für Internationale Pädagogische Forschung (2018), InfoWeb Weiterbildung, http://German Institute for International Educational Research.

Effenberger, A. et al. (2018), How do educational attainment and age influence the consequences of job loss? An empirical study using longitudinal individual data from Germany.

Eickelmann, B., W. Bos and J. Gerick (2015), Wie geht es weiter? Zentrale Befunde der Studie ICILS 2013 und mögliche Handlungs- und Entwicklungsperspektiven für Einzelschulen. Schulverwaltung NRW.

Euler and Severing (2016), Durchlässigkeit zwischen beruflicher und akademischer Bildung $P$ o s it io $n$ b e zie he $n$ Praxis gestalt e $n$ H in t e r gründ e k e n n e n, https://www.bertelsmannstiftung.de/fileadmin/files/BSt/Publikationen/GrauePublikationen/LL GP Durchlaessigkeit Praxis final.pdf (accessed on 29 November 2017).

European Commission, Directorate General for Employment, Social Affairs and Inclusion (2015), An in-depth analysis of adult learning policies and their effectiveness in Europe.

Forster, A. et al. (2016), "Vocational Education and Employment over the Life Cycle", Sociological Science, Vol. 3, pp. 473-494, http://dx.doi.org/10.15195/v3.a21.

Gaylor, C., N. Schöpf and E. Severing (2015), Wenn aus Kompetenzen berufliche Chancen werden, Bertelsmann Stiftung.

Goos, M., A. Salomons and A. Manning (2014), “Explaining Job Polarization: Routine-Biased Technological Change and Offshoring”, American Economic Review, Vol. 104/8, pp. 25092526.

Grundke, R. et al. (2017), "Having the right mix: The role of skill bundles for comparative advantage and industry performance in GVCs", OECD Science, Technology and Industry Working Papers, No. 2017/03, OECD Publishing, Paris, http://dx.doi.org/10.1787/892a4787en. 
Haan, P., A. Hammerschmid and C. Rowold (2017), "Geschlechtsspezifische Renten- und Gesundheitsunterschiede in Deutschland, Frankreich und Dänemark", DIW Wochenbericht, Vol. 84 (2017), pp. 971-974.

Hampf, F. and L. Woessmann (2016), "Vocational vs. General Education and Employment over the Life-Cycle: New Evidence from PIAAC", IZA Discussion Paper, No. 10298, IZA.

Hanushek, E. et al. (2017), "Coping with change: International differences in the returns to skills”, Economics Letters, Vol. 153, pp. 15-19, http://dx.doi.org/10.1016/j.econlet.2017.01.007.

Hanushek, E. et al. (2015), "Returns to skills around the world: Evidence from PIAAC", http://dx.doi.org/10.1016/j.euroecorev.2014.10.006.

Hanushek, E. et al. (2015), "General Education, Vocational Education, and Labor-Market Outcomes over the Life-Cycle *", http://hanushek.stanford.edu/sites/default/files/publications/hswz\%20vocational\%20final.pdf (accessed on 06 November 2017).

Hanushek, E. and L. Woessmann (2008), "The Role of Cognitive Skills in Economic Development", Journal of Economic Literature, Vol. 463, pp. 607-668, http://dx.doi.org/10.1257/jel.46.3.607.

Heublein, U. et al. (2017), “Zwischen Studienerwartungen und Studienwirklichkeit”, Forum Hochschule 2017.

Hoeckel, K. and R. Schwartz (2010), A Learning for Jobs Review of Germany. OECD Reviews of Vocational Education and Training., OECD, http://pacfiles.oecd.org/acrobatebook/9111091e.pdf (accessed on 09 December 2017).

Institut der deutschen Wirtschaft (2015), Berufsausbildung für Europas Jugend, Länderbericht Deutschland.

Janssen, S. et al. (2017), "The Shelf-life of Incumbent Workers in Times of Accelerating Technological Change: Evidence from a Reform of a Mandatory Training Regulation”, IZA conference paper, http://conference.iza.org/conference files/MacroEcon_2017/janssen_s6996.pdf (accessed on 13 December 2017).

Kis, V. and H. Windisch (2018), Making skills transparent: recognising vocational skills acquired through work-based learning, OECD Education Working Paper, OECD Publishing, Paris..

Kosse, F. et al. (2016), "The Formation of Prosociality: Causal Evidence on the Role of Social Environment”, IZA Discussion Paper, No. 9861, IZA.

Lima, F. (2012), Avaliação dos Cursos de Educação e Formação de Adultos e Formações Modulares: Certificadas: Empregabilidade e Remunerações.

Hanushek, E., S. Machin and L. Woessmann (eds.) (2016), Government-Sponsored Vocational Education for Adults, Elsevier.

Michelsen, C. (2018), Baukindergeld löst nicht die Probleme auf dem Wohnungsmarkt, DIW (German Institute for Economic Research), p. 286. 
Mohr, S., K. Troltsch and C. Gerhards (2015), Rückzug von Betrieben aus der beruflichen Ausbildung: Gründe und Muster, http://file:///C:/Users/fuentes a/Downloads/58cfaca4ebc65 $2015 \quad 12 \quad 14$ bibb report $04 \quad 20$ 15 barrierefrei.pdf.

Mullis, I. et al. (2017), PIRLS 2016 International Results in Reading., http://timssandpirls.bc.edu/pirls2016/international-results/.

OECD (2017), Economic Outlook 102, November, http://dx.doi.org/10.1787/05b705e7-en.

OECD (2017), Education at a Glance 2016, http://download.eiie.org/Docs/WebDepot/EaG2016 EN.pdf.

OECD (2017), Education at a Glance 2017: OECD Indicators, OECD Publishing, Paris, http://dx.doi.org/10.1787/eag-2017-en.

OECD (2017), Entrepreneurship at a Glance 2017, OECD Publishing, Paris, http://dx.doi.org/10.1787/entrepreneur aag-2017-en.

OECD (2017), Getting Skills Right: France, OECD Publishing, http://dx.doi.org/10.1787/9789264284456-en.

OECD (2017), Getting Skills Right: Good Practice in Adapting to Changing Skill Needs: A Perspective on France, Italy, Spain, South Africa and the United Kingdom, OECD Publishing, Paris, http://dx.doi.org/10.1787/9789264277892-en.

OECD (2017), Getting Skills Right: Italy, OECD Publishing, http://dx.doi.org/10.1787/9789264278639-en.

OECD (2017), OECD Economic Surveys: Switzerland 2017, http://dx.doi.org/10.1787/eco_surveys-che-2017-en.

OECD (2017), OECD Guidelines on Measuring the Quality of the Working Environment, OECD Publishing, Paris, http://dx.doi.org/10.1787/9789264278240-en.

OECD (2017), OECD Science, Technology and Industry Scoreboard 2017: The digital transformation, OECD Publishing, Paris, http://dx.doi.org/10.1787/9789264268821-en.

OECD (2017), OECD Skills Strategy Diagnostic Report: The Netherlands 2017, OECD Publishing, Paris, http://dx.doi.org/10.1787/9789264287655-en.

OECD (2017), OECD, The Governance of Land Use, OECD Publishing, Paris.

OECD (2017), Skills Outlook 2017, http://dx.doi.org/10.1787/9789264273351-en.

OECD (2017), Starting Strong 2017 - Key OECD Indicators on Early Childhood Education and Care., OECD Publishing.

OECD (2017), Taxation and skills, OECD Publishing, http://dx.doi.org/10.1787/9789264269385-en.

OECD (2016), Getting Skills Right: Sweden, OECD Publishing, http://dx.doi.org/10.1787/9789264265479-en.

OECD (2016), OECD Economic Surveys: Germany 2016, OECD Publishing, Paris, http://dx.doi.org/10.1787/eco_surveys-deu-2016-en.

OECD (2016), Skills matter : further results from the survey of adult skills., OECD Publishing, Paris, http://dx.doi.org/10.1787/9789264258051-en. 
OECD (2016), Starting Strong IV, Monitoring quality in early childhood education and care, Germany country note.

OECD (2015), Governing the City, OECD Publishing, Paris, http://dx.doi.org/10.1787/9789264226500-en.

OECD (2015), In It Together: Why Less Inequality Benefits All, OECD Publishing, Paris, http://dx.doi.org/10.1787/9789264235120-en.

OECD (2014), "Education Policy Outlook Germany”.

OECD (2014), OECD Skills Strategy Diagnostic Report: Austria, OECD Publishing.

OECD (2012), Starting Strong III - A Quality Toolbox for Early Childhood Education and Care.

OECD (2008), "Tertiary Education for the Knowledge Society, OECD Publishing, Paris".

OECD (2003), Beyond Rhetoric: Adult Learning Policies and Practices, OECD Publishing, Paris, http://dx.doi.org/10.1787/9789264199446-en.

Pekkarinena, T. (2009), "School Tracking and Intergenerational Income Mobility: Evidence from the Finnish Comprehensive School Reform", Journal of Public Economics, Vol. 93/78, pp. $965-73$.

Perini, L. (2014), "Who Benefits Most from University Education in Switzerland?”, Swiss Journal of Economics and Statistics, Vol. 150/2, pp. 119-59.

Peter, F. (2014), “Qualität der Kindertageseinrichtung beeinflusst kindliche Gesundheit”, $D I W$ Wochenbericht, Vol. 2014/18.

Philipp Deschermeier et al. (2017), "Bautätigkeit und Baubedarf fallen in Deutschland räumlich auseinander", IW-Kurzberichte 44.

Prognos AG (2016), Evaluation "Kultur macht stark. Bündnisse für Bildung": Bericht zum Evaluationszeitraum 2014 - 2015.

Roggenkamp, M. (2016), Trendanalyse - Berufl iche Aus- und Weiterbildung in Deutschland, bfw Berufsfortbildungswerk Gemeinnützige Bildungseinrichtung des DGB GmbH.

Sachverständigenrat (2017), Für eine zukunftsorientierte Wirtschaftspolitik - Jahresgutachten $2017 / 2018$.

Sachverständigenrat deutscher Stiftungen für Integration und Migration (2013), Segregation an deutschen Schulen. Ausmaß, Folgen und Handlungsempfehlungen., https://www.stiftungmercator.de/media/downloads/3_Publikationen/SVR_Studie_Bildungssegregation_Juli_2013. pdf.

Schmitz, S., K. Spieß and J. Stahl (2017), "Kindertageseinrichtungen: Ausgaben der Familien sind von 1996 bis 2015 mitunter deutlich gestiegen", DIW Wochenbericht, Vol. 41/2017.

Schober, B. and B. Pia (2017), "Not Just Any Child Care Center? Social and Ethnic Disparities in the Use of Early Education Institutions With a Beneficial Learning Environment, Early Education and Development", Early Education and Development, Vol. 28/8, pp. 1011-1034.

Schober, P. and C. Spieß (2014), "Die Kita-Qualität ist für das Erwerbsverhalten von Müttern mit Kleinkindern relevant - Zusammenhang eindeutiger in Ostdeutschland”, DIW Wochenbericht, Vol. 21.

Schober, P., C. Spieß and J. Stahl (2017), Gute Gründe für gute Kitas!, Friedrich-Ebert-Stiftung, Bonn. 
Stahl, J., P. Schober and C. Spiess (2017), "Parental socio-economic status and childcare quality: Early inequalities in educational opportunity?", Early Childhood Research Quarterly, http://dx.doi.org/10.1016/J.ECRESQ.2017.10.011.

StEG, D. (2016), Ganztagsschule: Bildungsqualität und Wirkungen ausserunterrichtlicher Angebote.

Tophoven, S. et al. (2017), Armutsmuster in Kindheit und Jugend, Längsschnittbetrachtungen von Kinderarmut, Bertelsmann Stiftung, https://www.bertelsmannstiftung.de/fileadmin/files/Projekte/Familie_und_Bildung/Studie_WB_Armutsmuster_in_Kin dheit und Jugend_2017.pdf.

Unterhofer, U. and K. Wrohlich (2017), "Fathers, Parental Leave and Gender Norms", DIW Discussion Papers, No. 1657, DIW Berlin.

Velten, S. and G. Herdin (2016), Anerkennung informellen und non-formalen Lernens in Deutschland, Bundesinstitut für Berufsbildung (BIBB).

Wissenschaftsrat (2014), Empfehlungen zur Gestaltung des Verhältnisses von beruflicher und akademischer Bildung.

Wittig, W. and F. Neumann (2016), Können belegen können, Bertelsmann Stiftung.

Wrohlich, K. and A. Zucco (2017), "Gender Pay Gap innerhalb von Berufen variiert erheblich", DIW Wochenbericht, Vol. 43/2017, pp. 955-961. 